\title{
Assessment of Urban Air Quality in Indonesia
}

\section{Muhayatun Santoso $^{1 *}$, Diah Dwiana Lestiani ${ }^{1}$, Syukria Kurniawati ${ }^{1}$, Endah Damastuti ${ }^{1}$, Indah Kusmartini ${ }^{1}$, Djoko Prakoso Dwi Atmodjo ${ }^{1}$, Dyah Kumala Sari ${ }^{1}$, Philip K. Hopke ${ }^{2}$, Rita Mukhtar ${ }^{3}$, Tamrin Muhtarom ${ }^{4}$, Agus Tjahyadi ${ }^{5}$, Sukadi Parian ${ }^{6}$, Nur Kholik ${ }^{7}$, Dimas Ageng Sutrisno ${ }^{8}$, Dwi Wahyudi ${ }^{9}$, Timora Diliyani Sitorus ${ }^{10}$, Jasmiyati Djamilus ${ }^{11}$, Ahmad Riadi ${ }^{12}$, Jen Supriyanto ${ }^{13}$, Nurhayana Dahyar ${ }^{14}$, Stenly Sondakh $^{15}$,} Karelise Hogendorp ${ }^{16}$, Nurdian Wahyuni ${ }^{17}$, I. Gede Bejawan ${ }^{18}$, Lalu Syakhrizal Suprayadi ${ }^{19}$

\author{
${ }^{1}$ Center for Applied Nuclear Science and Technology, National Nuclear Energy Agency (BATAN), Bandung, Indonesia \\ ${ }^{2}$ University of Rochester Medical Center, 601 Elmwood Ave, Rochester, NY 14642, USA \\ ${ }^{3}$ Ministry of Environmental and Forestry, Puspiptek, Serpong, Indonesia \\ ${ }^{4}$ The Environmental Protection Agency of Jakarta, Jl. Casablanca Kav. 1 Kuningan Jakarta Selatan, Indonesia \\ ${ }^{5}$ The Environmental Protection Agency of West Java, Jl Naripan 25 Bandung, Indonesia \\ ${ }^{6}$ Center for Accelerator Science and Technology, National Nuclear Energy Agency (BATAN), Yogyakarta, Indonesia \\ ${ }^{7}$ The Environmental Protection Agency of Center Java, Jl. Setiabudi, Komplek Diklat, Semarang, Indonesia \\ ${ }^{8}$ The Environmental Protection Agency of East Java, Jl. Wisata Menanggal 38, Surabaya, Indonesia \\ ${ }^{9}$ The Environmental Protection Agency of Surabaya city, Jl. Gubeng, Surabaya, Indonesia \\ ${ }^{10}$ The Environmental Protection Agency of North Sumatra, Medan, Indonesia \\ ${ }^{11}$ The Environmental Protection Agency of Pekanbaru City, Pekanbaru, Indonesia \\ ${ }^{12}$ The Environmental Protection Agency of Palangka Raya City, Jl. Tjilik Riwut, Palangka Raya \\ ${ }^{13}$ The Environmental Protection Agency of Balikpapan City, Jl. Jendral Sudirman, Balikpapan, Indonesia \\ ${ }^{14}$ The Environmental Protection Agency of Eco region of Sulawesi Maluku, Jl. Perintis Kemerdekaan, Makassar, Indonesia \\ ${ }^{15}$ The Environmental Protection Agency of North Sulawesi, Jl. 17 Agustus, Manado, Indonesia \\ ${ }^{16}$ The Environmental Protection Agency of Maluku, Ambon, Indonesia \\ ${ }^{17}$ The Environmental Protection Agency of Papua, Jayapura, Indonesia \\ ${ }^{18}$ The Environmental Protection Agency of Eco Region of Bali Nusa Tenggara, Denpasar Bali, Indonesia \\ ${ }^{19}$ The Environmental Protection Agency of West Nusa Tenggara, Mataram, Indonesia
}

\begin{abstract}
This study assessed the urban air quality in 16 large Indonesian cities on the islands of Java, Sumatra, Kalimantan, Sulawesi, Maluku, and Papua from 2010 till 2017. 24-h samples of airborne particulate matter (PM) in two size fractions, $\mathrm{PM}_{2.5}\left(<2.5 \mu \mathrm{m}\right.$ in aerodynamic diameter) and $\mathrm{PM}_{2.5-10}(2.5-10 \mu \mathrm{m}$ in aerodynamic diameter), were collected weekly using a Gent stacked filter unit sampler and then analyzed for their mass concentrations, black carbon (BC) content, and elemental compositions. The majority of the average annual $\mathrm{PM}_{2.5}$ concentrations measured at the Java sites (Bandung, Jakarta, Semarang, and Surabaya) exceeded the Indonesian annual ambient air quality standard $\left(15 \mu \mathrm{g} \mathrm{m}^{-3}\right)$, although the other tested locations, excluding Pekanbaru and Palangka Raya, exhibited values below the standard. During the forest fire episodes of 2015, the average daily $\mathrm{PM}_{2.5}$ concentrations in Pekanbaru and Palangka Raya rose above the national daily ambient standard $\left(65 \mu \mathrm{g} \mathrm{m}^{-3}\right)$. The percentage of BC, which is associated with traffic emission and biomass burning, averaged between $15 \%$ and $26 \%$ (a significant fraction) in the $\mathrm{PM}_{2.5}$. The concentrations of the major elements in the $\mathrm{PM}_{2.5}, \mathrm{viz}$., $\mathrm{Si}, \mathrm{S}, \mathrm{K}, \mathrm{Fe}, \mathrm{Zn}$, and $\mathrm{Pb}$, varied widely from site to site, although all of the locations displayed enhanced levels of the crustal elements $\mathrm{Si}$ and $\mathrm{S}$, which originated from unpaved roads and volcanic eruptions, and vehicle fuel, forest fires, and volcanic emissions, respectively. Significantly higher concentrations of heavy metals ( $\mathrm{Fe}, \mathrm{Zn}$, and $\mathrm{Pb}$ in Surabaya and $\mathrm{Pb}$ in $\mathrm{Tangerang}$ ) were found at the heavily industrialized sites, demonstrating the effect of local industrial emissions on air quality. Our results, which are based on a crucial survey of PM concentrations and compositions in Indonesia, provide a scientific basis for
\end{abstract}

\footnotetext{
* Corresponding author.

Tel.: 62-22-250-3997; Fax; 62-22-250-4081

E-mail address: hayat@batan.go.id
} 
developing and improving various air quality policies in the nation, including an early warning system for severe pollution events.

Keywords: $\mathrm{PM}_{2.5} ; \mathrm{PM}_{10}$; $\mathrm{BC}$; Chemical composition; Indonesia.

\section{INTRODUCTION}

Air pollution has become an important global problem that requires serious attention because of its impact on human health and environmental quality (Brauer et al., 2016; Yin et al., 2017; Lelieveld et al., 2019). The degradation of ambient air quality, especially in major cities, needs major improvements. In Indonesia, air pollution is one of many serious environmental problems facing major cities due to the population growth, increasing economic activity, and associated transportation and industrial activities. Since 2006, Indonesia has been conducting an urban air quality improvement (UAQi) project with the vision of "Clean and Healthy Urban Air in Indonesia in 2020." The project developed various strategies for each issue related to urban air quality improvement on the national and local levels in several large cities (Bappenas, 2006). However, this program was not fully implemented due to the lack of financial resources and air quality expertise.

Up to 2015, Indonesian authorities operated an air quality monitoring network that utilized a variety of techniques such as the Air Quality Management System (AQMS), a network for continuous automated monitors for $\mathrm{CO}, \mathrm{SO}_{2}, \mathrm{NO}_{x}, \mathrm{O}_{3}$, and $\mathrm{PM}_{10}(\mathrm{PM}<10 \mu \mathrm{m})$ in 10 cities combined with passive monitors to measure $\mathrm{NO}_{2}$ and $\mathrm{SO}_{2}$ concentrations in 33 provinces. Due to the limited resources, the AQMS does not operate effectively in all 10 cities since the equipment upkeep and calibrations require more support than were available (P3KLL, 2010). Additionally, the AQMS did not monitor $\mathrm{PM}_{2.5}(\mathrm{PM}<2.5 \mu \mathrm{m})$ that is an important parameter because of its negative impacts on public health and urban visibility. Therefore, $\mathrm{PM}_{2.5}$ monitoring is necessary. In 2016, the Indonesian Ministry of Environment and Forestry (MoEF) deployed a new $\mathrm{AQMS}$ network in major cities to monitor 7 parameters $\left(\mathrm{SO}_{2}, \mathrm{O}_{3}, \mathrm{CO}, \mathrm{NO}_{2}, \mathrm{HC}, \mathrm{PM}_{10}\right.$, and $\left.\mathrm{PM}_{2.5}\right)$. By 2017, 7 AQMS stations (Palembang, Jambi, Padang, Pekanbaru, Pontianak, Banjarmasin, and Palangka Raya) were in operation and the data can be retrieved online (Menlhk, 2018). This monitoring network will continue to be developed.

Based on a formal memorandum of understanding between the National Nuclear Energy Agency of Indonesia (BATAN) and MoEF signed in 2011 and extended in 2016, BATAN and MoEF proposed an IAEA technical cooperation project as a national program to monitor air quality in cities covering most of the larger islands in Indonesia. The project's objective was to contribute to the improvement of air quality in Indonesia by applying advanced nuclear analytical techniques (NATs) to the assessment of airborne particulate matter pollution. Nuclear analytical techniques such as neutron activation analysis, X-ray fluorescence, and ion beam analysis (Hopke et al., 2008; Santoso et al., 2011; Cohen et al., 2014) are highly suitable for characterizing the elemental compositions of PM samples. The measurement of the elemental composition of the particulate matter is a key factor in utilization of the data for the determination of possible sources, whose identification and apportionment is an important step in air quality management. To evaluate the effectiveness of the control programs and to support planning, data that are characteristic of urban air quality are needed.

The distribution of mass concentration of $\mathrm{PM}_{2.5}$ collected at urban and suburban areas in Indonesia have been reported previously. Santoso et al. (2008) reported the mean $\mathrm{PM}_{2.5}$ concentrations in Bandung and Lembang between 2002 and 2004 were $14.03 \pm 6.86$ and $11.88 \pm 6.60 \mu \mathrm{g} \mathrm{m}^{-3}$, respectively. The mean $\mathrm{PM}_{2.5-10}$ concentrations in Bandung and Lembang were $17.64 \pm 9.42$ and $7.10 \pm 7.04 \mu \mathrm{g} \mathrm{m}^{-3}$, respectively. Santoso et al. (2011) reported that $\mathrm{PM}_{2.5}$ concentrations in the Serpong-Tangerang area, a region near Jakarta, had high concentrations of $\mathrm{Pb} .24-\mathrm{h} \mathrm{PM}_{2.5}$ values at the industrial sites ranged from 15 to $42 \mu \mathrm{g} \mathrm{m}^{-3}$, while at the residential sites, values ranged from 9 to $36 \mu \mathrm{g} \mathrm{m}^{-3}$. The $\mathrm{PM}_{2.5}$ concentrations measured in Jakarta at an arterial roadside were higher than the $\mathrm{PM}_{2.5}$ at the urban site in Bandung. The mean concentration of $\mathrm{PM}_{2.5}$ and $\mathrm{PM}_{10}$ in Jakarta were 25.76 and $75.20 \mu \mathrm{g} \mathrm{m}^{-3}$, respectively. Most $\mathrm{PM}_{2.5}$ values measured in Jakarta exceeded the Indonesian annual ambient air quality standard of $15 \mu^{-3 ~ ~ m^{-3}}$ (Santoso et al., 2013a). The determination of chemical elements' concentrations in airborne particulate matter collected in suburban area of Lembang, Indonesia, was reported by Lestiani et al. (2013). Chemical elements including $\mathrm{Mg}, \mathrm{V}, \mathrm{Cr}, \mathrm{Mn}, \mathrm{Fe}, \mathrm{Co}, \mathrm{Ni}, \mathrm{Cu}, \mathrm{Zn}, \mathrm{As}, \mathrm{Hg}$, and $\mathrm{Pb}$ were determined. In the fine fraction, principal component analysis (PCA) studies found sources such as vehicular emissions and biomass burning. Lestari and Mauliadi (2009) reported the sources of fine and coarse particulate matter in Bandung using positive matrix factorization (PMF). Different numbers of source factors were resolved during the dry and wet seasons.

Although previous studies have presented the chemical composition of $\mathrm{PM}_{2.5}$ and source identification results, there has not been a comprehensive study conducted for multiple cities across Indonesia covering more than 3 years that provides fine and coarse particle mass concentration and composition. The objective of the current study was to provide an initial assessment of particulate air pollution including $\mathrm{PM}_{2.5}$ and $\mathrm{PM}_{10}$ total mass concentrations, $\mathrm{BC}$, and elemental concentration in 16 cities across Indonesia in the period 2010-2017.

\section{METHODS}

Sampling was conducted at 17 sites in 16 large cities in Indonesia. The sampling locations for these 16 cities are shown in Fig. 1. There are 7 sites on the island of Java (Jakarta, 


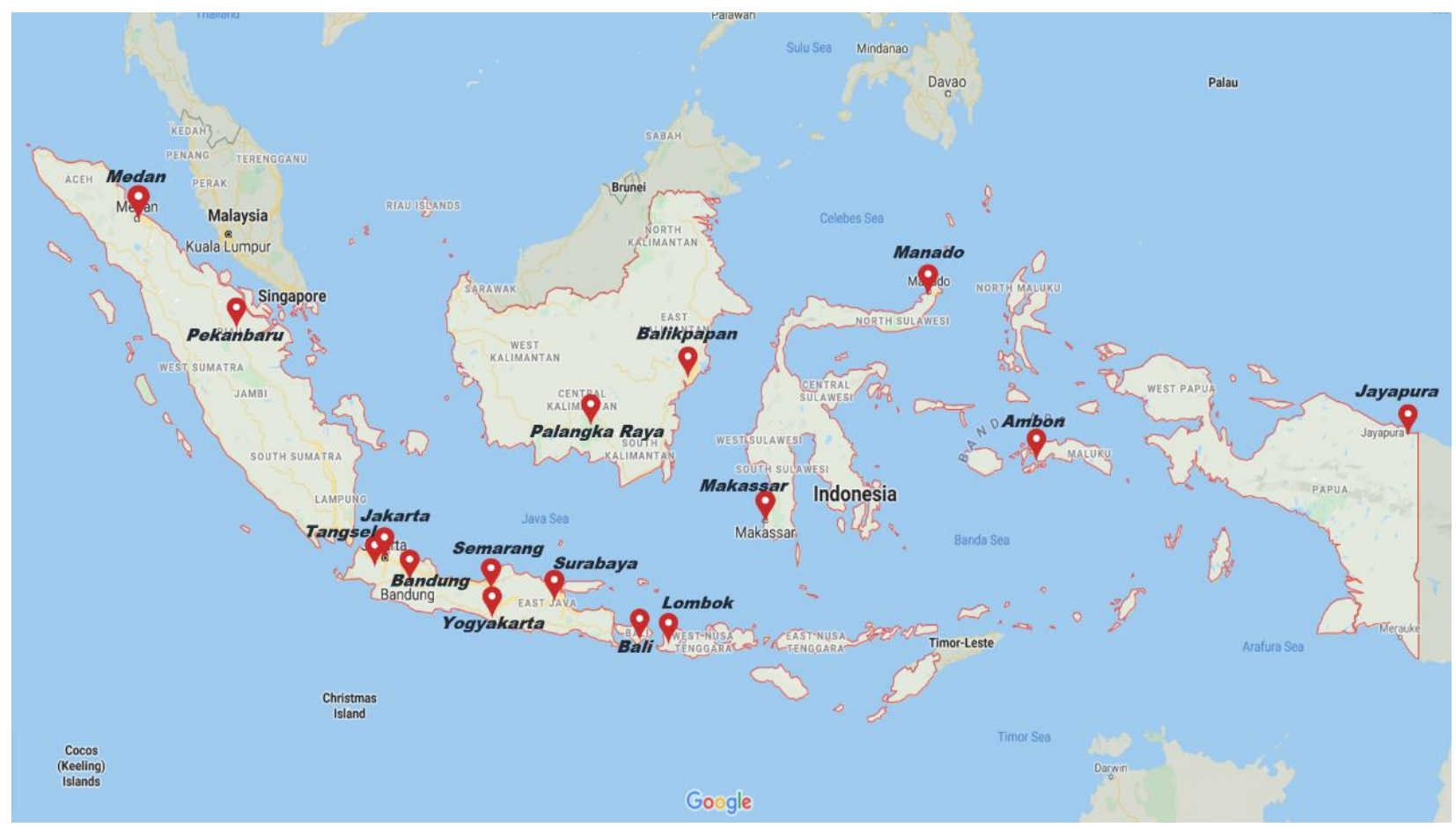

Fig. 1. Locations of sampling sites in Indonesia (source: Google Maps, 2018).

Tangerang, Bandung, Yogyakarta, Semarang, and 2 sites in Surabaya), 2 sites on Sumatra (Pekanbaru and Medan), 2 sites on Kalimantan (Palangka Raya and Balikpapan), 2 sites on Sulawesi (Makassar and Manado), 1 site on Maluku (Ambon), 1 site on Papua (Jayapura), 1 site on Bali (Denpasar), and 1 site on West Nusa Tenggara (Mataram).

Jakarta is the capital and the mega-city of Indonesia with a 2017 population of 10,177,924 (BPS, 2018). Many buildings, highways, and small- to large-scale factories are situated in and around the city. Tangerang is an independent city in Banten province near Jakarta and categorized as an industrial city. Bandung is located about $150 \mathrm{~km}$ southeast of Jakarta. It is the provincial capital of West Java and is categorized as an industrial city. Many small-scale factories are located around the city. Commercial activities are mostly concentrated in the center of the city, while industrial activities are concentrated on the west and east sides of Bandung. Yogyakarta is the capital city of special region of Yogyakarta, with an area of $32.5 \mathrm{~km}^{2}$. It is the only royal city in Indonesia still ruled by a monarchy. Near the city is Mount Merapi, the most active volcano in Indonesia. Semarang is the provincial capital of Central Java and the sixth-largest Indonesian city. Surabaya is Indonesia's second-largest city with a population of over 2.8 million and industrial activities such as cement factories, smelters, and other metal industries.

Pekanbaru is the capital of Riau province that is growing rapidly with the development of industries especially those related to petroleum and is a major economic center on the island of Sumatra. Medan is the capital of the Indonesian province of North Sumatra. It is a multicultural metropolitan area and a busy trading center.

Palangka Raya is the capital of Central Kalimantan province with an area of $2400 \mathrm{~km}^{2}$ and part of its territory is still forest, including protected forest, nature conservation and Tangkiling Forest. Palangka Raya has the largest area in Indonesia, equivalent to 3.6 times the area of Jakarta. Balikpapan is a city in East Kalimantan province serving as a business and industrial center. The city's economy is the largest in Kalimantan, which is based on an industrial sector dominated by oil and gas, trade and service industries.

Makassar is the largest metropolitan city in Eastern Indonesia, having an area of $175.77 \mathrm{~km}^{2}$ and a population of more than 1.5 million people, the fifth-largest city in Indonesia. Manado is the capital of the province of North Sulawesi with a land area of $157 \mathrm{~km}^{2}$, a coastline of $18.7 \mathrm{~km}$, and a population of 1.2 million. The city is surrounded by hills and mountain ranges. The economy of Manado consists of the trade, hotels and restaurants, transportation and communications, and other aspects of the service sector.

Ambon is the center of the port, tourism and education for the Maluku Islands region. Ambon has a total area of $377 \mathrm{~km}^{2}$ or two-fifths of Ambon Island that consists of land area of $359.45 \mathrm{~km}^{2}$ and waters of $17.55 \mathrm{~km}^{2}$ with a coastline of $98 \mathrm{~km}$.

Jayapura is the capital of Papua province, with an area of $940 \mathrm{~km}^{2}$. The topography of this area is quite varied, from the plains to the slopes and hills or mountains ranging to 700 meters above sea level.

Denpasar is the capital of Bali province, famous for its tourism industry giving it a high income per capita in Bali. The city of Mataram is the capital of West Nusa Tenggara province, has a topographic area at an altitude of less than 50 meters above sea level and is close to Mount Rinjani.

Sampling at these 17 sites was conducted using Gent stacked filter unit (SFU) particle samplers to collect $\mathrm{PM}_{2.5-10}$ and $\mathrm{PM}_{2.5}$ size fractions (Hopke et al., 1997). The samples 
were collected at least once per week for $24 \mathrm{~h}$ at urban residential sites on $8-\mu \mathrm{m}$ pore coated Nuclepore filters for the coarse fraction sample and on $0.4-\mu \mathrm{m}$ pore Nuclepore filters for the fine fraction sample. Most samples were collected on weekdays. The aerosol masses of both $\mathrm{PM}_{2.5-10}$ and $\mathrm{PM}_{2.5}$ fractions were determined by weighing the filters before and after exposure, then divided by the sampled air volume to obtain the $\mathrm{PM}_{2.5}$ and $\mathrm{PM}_{2.5-10}$ concentrations $\left(\mu \mathrm{g} \mathrm{m}^{-3}\right)$. The $\mathrm{PM}_{10}$ concentrations were obtained by summing these two values. More than 3300 pairs of samples were collected from the 16 cities across Indonesia. Information regarding the sampling sites and the measurement periods are provided in Table 1.

Light absorbing carbon (black carbon $[\mathrm{BC}]$ ) in the samples was determined by reflectance measurement using an EEL Model 43D smoke stain reflectometer that measures the reduction in reflected white light (Biswas et al., 2003; Coulson and Ellison, 1963; Commins and Waller, 1967). Secondary standards of known black carbon concentrations are used to calibrate the reflectometer (Biswas et al., 2003; Begum et al., 2011). The BC concentrations were defined based on the amount of light that is absorbed by the filter sample and an assumed mass absorption coefficient $\left(7 \mathrm{~m}^{2} \mathrm{~g}^{-1}\right.$, with an exposed area of $12.57 \mathrm{~cm}^{2}$ ) to convert reflectance measurement to mass that can then be divided by sample volume to give micrograms per cubic meter. A linear correlation of absorption (BC) by this method and elemental carbon (EC) measured by a thermo-optical analyzer has been demonstrated even for high concentrations (Salako et al., 2012).

The collected samples were analyzed for their multiple elemental concentrations using an Epsilon 5 ED-XRF (Panalytical Ltd.) that has 9 secondary targets $\left(\mathrm{Fe}, \mathrm{CaF}_{2}, \mathrm{Ge}\right.$, $\mathrm{Zr}, \mathrm{CeO}_{2}, \mathrm{Mo}, \mathrm{Ag}, \mathrm{Al}$ and $1 \mathrm{Barkla}$ polarizing target $\left[\mathrm{Al}_{2} \mathrm{O}_{3}\right]$ ). The calibration was done using multi-standard reference material. For method validation, 2783 National Institute of Standards and Technology (NIST) Standard Reference Material (SRM) samples were periodically analyzed. These methods were described in detail by Landsberger and Creatchman (1999), and Santoso and Lestiani (2014). Major elements in $\mathrm{PM}_{2.5}$ including $\mathrm{Si}, \mathrm{S}, \mathrm{K}, \mathrm{Fe}, \mathrm{Zn}$, and $\mathrm{Pb}$ will be discussed. The detection limits of these elements were 5.9, $10.4,1.9,3.8,2.9$, and $6.2 \mathrm{ng} \mathrm{m}^{-3}$, respectively.

\section{RESULTS AND DISCUSSION}

\section{Particulate Matter Concentrations}

Air pollution has received attention in several large cities in Indonesia because there is a tendency of decreasing air quality in these cities. Although there are ongoing programs that have been conducted to control it, the results obtained from this study showed that the air quality of several areas fell below the Indonesian standards especially for annual average $\mathrm{PM}_{2.5}$. A total of 6672 samples were collected from 17 sites in 16 cities in Indonesia and analyzed for mass and chemical composition including $\mathrm{BC}$. The distribution of $\mathrm{PM}_{2.5}, \mathrm{PM}_{2.5-10}$, and $\mathrm{BC}$ concentrations for each of the 17 sites (7 sites on Java island and 10 outside Java) in period between 2010 and 2017 are summarized in Table 2.

In Table 2 are summary statistics for the samples collected between 2010 and 2017. Sampling at the various sites occurred over differing time periods as given in Table 1 . The time series plots for 17 sites are provided in Figs. S1-S17 (in Supplementary Information).

The Yogyakarta data presented in Table 2 includes all data from 2010 to 2017 except the samples collected on 14 February 2014 when the eruption of Mount Kelud occurred. The mass concentrations of $\mathrm{PM}_{2.5}$ and $\mathrm{PM}_{2.5-10}$ at the time of the eruption of Kelud were 10 times greater compared to the remaining data for Yogyakarta. The time series plots for the Yogyakarta sites is provided in Fig. S7.

The data presented in Table 2 for Palangka Raya does not include data from monitoring during a large forest fire in 2015. The results obtained at the end of October 2015 showed the mass concentration of $\mathrm{PM}_{2.5}$ reached more than 5 times the Indonesian daily standard $\left(65 \mu \mathrm{g} \mathrm{m}^{-3}\right)$. These

Table 1. The information of sampling sites from which data are reported.

\begin{tabular}{|c|c|c|c|c|c|}
\hline No & Site & Latitude & Longitude & Period & Site Description \\
\hline 1 & Ambon & ${\mathrm{S} 03^{\circ} 41^{\prime} 54.68^{\prime \prime}}$ & E $128^{\circ} 10^{\prime} 25.22^{\prime \prime}$ & 14 Mar 2013-22 Dec 2017 & Urban \\
\hline 2 & Balikpapan & $\mathrm{S} 01^{\circ} 16^{\prime} 37.4^{\prime \prime}$ & E $116^{\circ} 48^{\prime} 35.6^{\prime \prime}$ & 24 Aug 2013-24 Nov 2017 & Urban \\
\hline 3 & Bandung & S $06^{\circ} 55^{\prime} 10.9^{\prime \prime}$ & E $107^{\circ} 36^{\prime} 39.1^{\prime \prime}$ & 8 May 2012-26 Dec 2017 & Urban \\
\hline 4 & Denpasar & S $08^{\circ} 40^{\prime} 09.09^{\prime \prime}$ & E $115^{\circ} 14^{\prime} 09.31^{\prime \prime}$ & 19 Sep $2012-17$ Oct 2017 & Urban \\
\hline 5 & Jakarta & $\mathrm{S} 06^{\circ} 13^{\prime} 34.08^{\prime \prime}$ & E $106^{\circ} 50^{\prime} 04.42^{\prime \prime}$ & 5 Mar 2010-28 Dec 2017 & Mega city \\
\hline 6 & Jayapura & S $02^{\circ} 33^{\prime} 43.42^{\prime \prime}$ & E $140^{\circ} 41^{\prime} 30.69^{\prime \prime}$ & 10 Apr 2013-15 Aug 2017 & Suburban \\
\hline 7 & Makassar & $\mathrm{S} 05^{\circ} 05^{\prime} 08.72^{\prime \prime}$ & E $119^{\circ} 31^{\prime} 04.75^{\prime \prime}$ & 8 Oct 2012-21 Dec 2017 & Urban \\
\hline 8 & Manado & $\mathrm{N} 01^{\circ} 28^{\prime} 04.9^{\prime \prime}$ & E $124^{\circ} 50^{\prime} 42.1^{\prime \prime}$ & 10 Oct $2013-26$ Dec 2017 & Urban \\
\hline 9 & Mataram & $\mathrm{S} 08^{\circ} 35^{\prime} 26.45^{\prime \prime}$ & E $116^{\circ} 05^{\prime} 39.71^{\prime \prime}$ & 10 Dec 2013-31 Dec 2017 & Urban \\
\hline 10 & Medan & $\mathrm{N} 03^{\circ} 34^{\prime} 54.82^{\prime \prime}$ & E $98^{\circ} 40^{\prime} 28.46^{\prime \prime}$ & 30 Mar 2014-27 Dec 2017 & Urban \\
\hline 11 & Palangka Raya & S $02^{\circ} 10^{\prime} 30.72^{\prime \prime}$ & E $113^{\circ} 52^{\prime} 49.26^{\prime \prime}$ & 6 Oct 2011-22 Dec 2017 & Suburban \\
\hline 12 & Pekanbaru & $\mathrm{N} 00^{\circ} 30^{\prime} 38.54^{\prime \prime}$ & E $101^{\circ} 26^{\prime} 50.14^{\prime \prime}$ & 12 Mar 2012-31 Dec 2017 & Urban \\
\hline 13 & Semarang & S $07^{\circ} 03^{\prime} 27.38^{\prime \prime}$ & E $110^{\circ} 24^{\prime} 40.50^{\prime \prime}$ & 5 Mar 2012-13 Dec 2017 & Urban \\
\hline \multirow[t]{2}{*}{14} & Surabaya_1 & S $07^{\circ} 20^{\prime} 46.43^{\prime \prime}$ & E $112^{\circ} 44^{\prime} 03.12^{\prime \prime}$ & 1 Jun 2015-28 Dec 2017 & Urban \\
\hline & Surabaya_2 & S $07^{\circ} 18^{\prime} 44.68^{\prime \prime}$ & E $112^{\circ} 47^{\prime} 20.55^{\prime \prime}$ & 6 Mar 2012-31 Dec 2017 & Urban \\
\hline 15 & Tangerang & $\mathrm{S} 06^{\circ} 21^{\prime} 02.5^{\prime \prime}$ & E $106^{\circ} 40^{\prime} 03.5^{\prime}$ & 15 Oct $2010-28$ Dec 2017 & Urban \\
\hline 16 & Yogyakarta & S $07^{\circ} 46^{\prime} 39.6^{\prime \prime}$ & E $110^{\circ} 24^{\prime} 51.7^{\prime \prime}$ & 8 Nov 2010-27 Dec 2017 & Urban \\
\hline
\end{tabular}


Table 2. Statistical values of $\mathrm{PM}_{2.5}, \mathrm{PM}_{2.5-10}$ and $\mathrm{BC}$ concentrations $\left(\mu \mathrm{g} \mathrm{m}^{-3}\right)$ of the 17 sites in Indonesia

\begin{tabular}{|c|c|c|c|c|c|c|c|c|c|c|c|c|c|}
\hline \multirow{2}{*}{ No } & \multirow{2}{*}{ Island } & \multirow{2}{*}{ City } & \multirow{2}{*}{$\mathrm{N}$} & \multicolumn{4}{|c|}{$\mathrm{PM}_{2.5}$ Concentration } & \multicolumn{4}{|c|}{$\mathrm{PM}_{2.5-10}$ Concentration } & \multirow{2}{*}{$\begin{array}{l}\text { BC } \\
\text { Mean }\end{array}$} & \multirow{2}{*}{$\frac{\mathrm{BC} / \mathrm{PM}_{2.5}}{\%}$} \\
\hline & & & & Mean & Median & Min & $\operatorname{Max}$ & Mean & Median & Min & Max & & \\
\hline 1 & Java & Bandung & 215 & $18 \pm 8$ & 18 & 2 & 56 & $24 \pm 9$ & 23 & 4 & 61 & 3.5 & 22 \\
\hline 2 & & Jakarta & 249 & $17 \pm 8$ & 17 & 1 & 70 & $28 \pm 12$ & 27 & 2 & 70 & 3.3 & 21 \\
\hline 3 & & Semarang & 235 & $16 \pm 8$ & 16 & 2 & 45 & $13 \pm 9$ & 11 & 2 & 84 & 3.1 & 22 \\
\hline \multirow[t]{2}{*}{4} & & Surabaya_1 & 62 & $15 \pm 5$ & 15 & 6 & 27 & $7 \pm 2$ & 6 & 22 & 4 & 3.2 & 22 \\
\hline & & Surabaya_2 & 208 & $16 \pm 5$ & 16 & 5 & 44 & $20 \pm 10$ & 19 & 6 & 99 & 3.6 & 23 \\
\hline 5 & & Tangerang & 328 & $14 \pm 7$ & 15 & 1 & 38 & $14 \pm 8$ & 12 & 2 & 44 & 2.5 & 20 \\
\hline 6 & & Yogyakarta $^{a}$ & 340 & $11 \pm 8$ & 10 & 1 & 35 & $13 \pm 8$ & 11 & 2 & 74 & 2.4 & 23 \\
\hline 7 & Outside & Ambon & 119 & $8 \pm 4$ & 7 & 3 & 31 & $7 \pm 4$ & 7 & 1 & 24 & 1.4 & 20 \\
\hline 8 & Java & Balikpapan & 141 & $10 \pm 6$ & 8 & 1 & 37 & $11 \pm 8$ & 10 & 1 & 46 & 1.5 & 16 \\
\hline 9 & & Denpasar & 178 & $13 \pm 5$ & 13 & 1 & 32 & $16 \pm 7$ & 16 & 3 & 44 & 2.8 & 24 \\
\hline 10 & & Jayapura & 144 & $5 \pm 3$ & 4 & 1 & 15 & $6 \pm 3$ & 5 & 1 & 24 & 0.7 & 16 \\
\hline 11 & & Makassar & 184 & $12 \pm 7$ & 10 & 2 & 49 & $8 \pm 7$ & 5 & 1 & 47 & 2.8 & 26 \\
\hline 12 & & Manado & 172 & $7 \pm 5$ & 6 & 1 & 32 & $9 \pm 5$ & 7 & 2 & 40 & 1.1 & 18 \\
\hline 13 & & Mataram & 144 & $10 \pm 5$ & 10 & 1 & 23 & $14 \pm 7$ & 13 & 1 & 41 & 1.8 & 18 \\
\hline 14 & & Medan & 115 & $10 \pm 6$ & 9 & 1 & 30 & $20 \pm 7$ & 19 & 8 & 47 & 1.9 & 18 \\
\hline 15 & & Palangka Raya ${ }^{\mathrm{b}}$ & 272 & $8 \pm 7$ & 5 & 1 & 41 & $10 \pm 8$ & 9 & 1 & 74 & 1.1 & 15 \\
\hline 16 & & Pekanbaru & 230 & $16 \pm 12$ & 15 & 2 & 96 & $26 \pm 21$ & 2 & 1 & 157 & 2.7 & 19 \\
\hline
\end{tabular}

${ }^{\text {a }}$ Sample collected on 14 Feb 2014 during the eruption of Mt. Kelud is not counted.

b Samples collected on 22-27 Oct 2015 when there was a large forest fire are not counted.

results adversely affected air quality locally as well as regionally. The time series plots for Palangka Raya sites are provided in Fig. S16.

Figs. 2 and 3 show the site-by-site $\mathrm{PM}_{2.5}$ and $\mathrm{PM}_{10}$ data distribution, respectively, including special event data, such as the Kelud volcanic eruption in Java and forest fires that occurred in Sumatra and Kalimantan. The whisker plot represents $25^{\text {th }}$ and $75^{\text {th }}$ percentile values, outliers, median (solid black line in the box), mean (red line). Error bars represent the $5^{\text {th }}$ and $95^{\text {th }}$ percentile values. In Fig. 2, the Indonesian annual standard of $15 \mu \mathrm{g} \mathrm{m}^{-3}$ (spanned horizontal line) and 24-h standard of $65 \mathrm{\mu g} \mathrm{m}^{-3}$ (dashed line) are shown, while in Fig. 3, the U.S. annual standard of $50 \mu \mathrm{g} \mathrm{m}^{-3}$ (spanned horizontal line) and 24-h of standard $150 \mu \mathrm{g} \mathrm{m}^{-3}$ (dashed line) are shown. High mass concentrations in Bandung and Yogyakarta resulted from the Kelud volcano eruption, as seen in Figs. S1 and S7, respectively.

The 2014 volcanic event significantly influenced air quality especially in Yogyakarta because volcanic ash was dispersed across an area of more than $500 \mathrm{~km}$ from the source (Lestiani et al., 2018). The time series of $\mathrm{PM}_{2.5}$ and $\mathrm{PM}_{10}$ concentrations in Yogyakarta before and after the eruption of Mount Kelud are shown in Fig. 4. The mass concentrations of $\mathrm{PM}_{2.5}$ and $\mathrm{PM}_{10}$ in Yogyakarta during the eruption episode reached 128 and $592 \mu \mathrm{g} \mathrm{m}^{-3}$, respectively, 10 times higher than $\mathrm{PM}_{2.5}$ under normal conditions, and even higher for $\mathrm{PM}_{10}$. The site in Yogyakarta is $283 \mathrm{~km}$ west of the volcano, while Semarang and Surabaya are located $318 \mathrm{~km}$ northwest and $131 \mathrm{~km}$ northeast of the volcano, respectively. Yogyakarta received the highest impact compared to the other sites because during the eruption, the volcano ejected $17 \mathrm{~km}$ into the atmosphere, and the wind blew strongly to the west (Kristiansen et al., 2015).

High concentrations of $\mathrm{PM}_{2.5}$ and $\mathrm{PM}_{10}$ in Palangka Raya occurred during the forest fires in October 2015. This event was included in Figs. 2, 3, and S16. The observed $\mathrm{PM}_{2.5}$ and $\mathrm{PM}_{10}$ concentration reached 377 and $710 \mu \mathrm{g} \mathrm{m}^{-3}$, respectively. The time series of $\mathrm{PM}_{2.5}$ and $\mathrm{PM}_{10}$ concentrations before and after the 2015 forest fires in Palangka Raya are shown in Fig. 5. The impact of the 2015 forest fires episode on air quality in Palangka Raya was significantly higher with PM concentrations that were 10-100 times the normal values (Fig. S16). Similar results were reported by Sulong et al. (2017). During October 2015, the concentration of $\mathrm{PM}_{2.5}$ in Kuala Lumpur reached $72.3 \pm 38.0 \mu \mathrm{g} \mathrm{m}^{-3}$. The air quality degradation during these haze episodes not only affected human health (especially children and old people) but also the economy due to direct illness costs and lost productivity (Othman et al., 2018). The fires in 2015 affected the air quality more than the fires event in the previous year (Fig. S16). A very dry period from July to October 2015 driven by very strong El Niño conditions in 2015 resulted in more intense fires (Latif et al., 2018). Compared to 2012, the $\mathrm{PM}_{2.5}$ concentrations during forest fires were around 7-8 times higher than normal conditions (Lestiani et al., 2019). Thus, efforts to reduce the occurrence of large fires are enforced by the government and their resulting consequences need to be continued.

The distributions of the $\mathrm{PM}_{2.5}$-to- $\mathrm{PM}_{10}$ ratio for the 17 sites show a wide range of values. The average ratios of $\mathrm{PM}_{2.5}$ to $\mathrm{PM}_{10}$ for Bandung, Jakarta, Semarang, Surabaya, Tangerang, and Yogyakarta on Java were 0.43, 0.40, 0.55, $0.46,0.51$, and 0.47 , respectively. For the sites outside Java in Ambon, Balikpapan, Denpasar, Jayapura, Makassar, Manado, Mataram, Medan, Palangka Raya, and Pekanbaru, the average ratios were $0.53,0.49,0.44,0.44,0.64,0.43$, $0.41,0.33,0.45$, and 0.39 , respectively. 12 cities had ratios less than 0.5 indicating considerable involvement of higher coarse particle masses. Alternatively, the urban sites in Ambon, Makassar, Semarang and Tangerang had ratios higher than 0.5 due to greater influence from traffic emissions. 


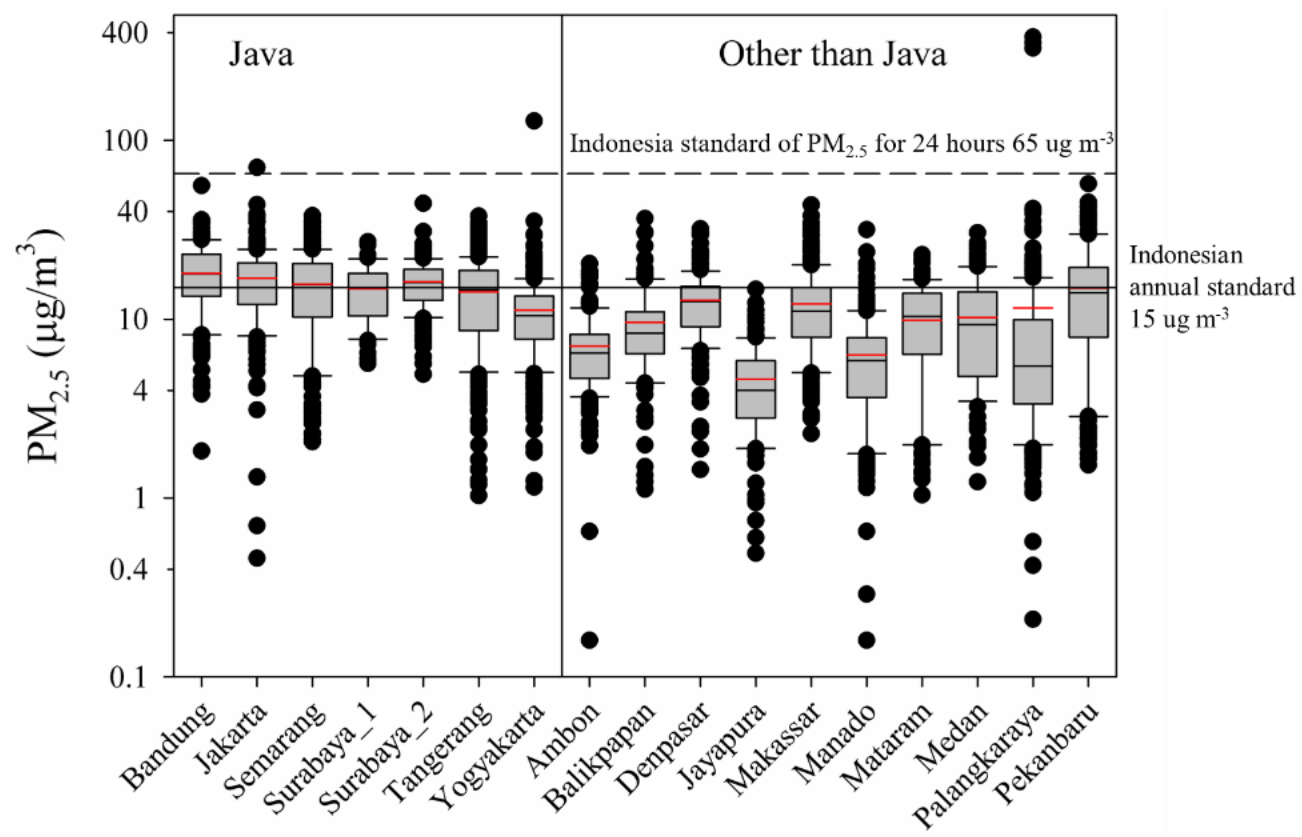

Fig. 2. Box-and-whisker plots of the $\mathrm{PM}_{2.5}$ distributions across Indonesia.

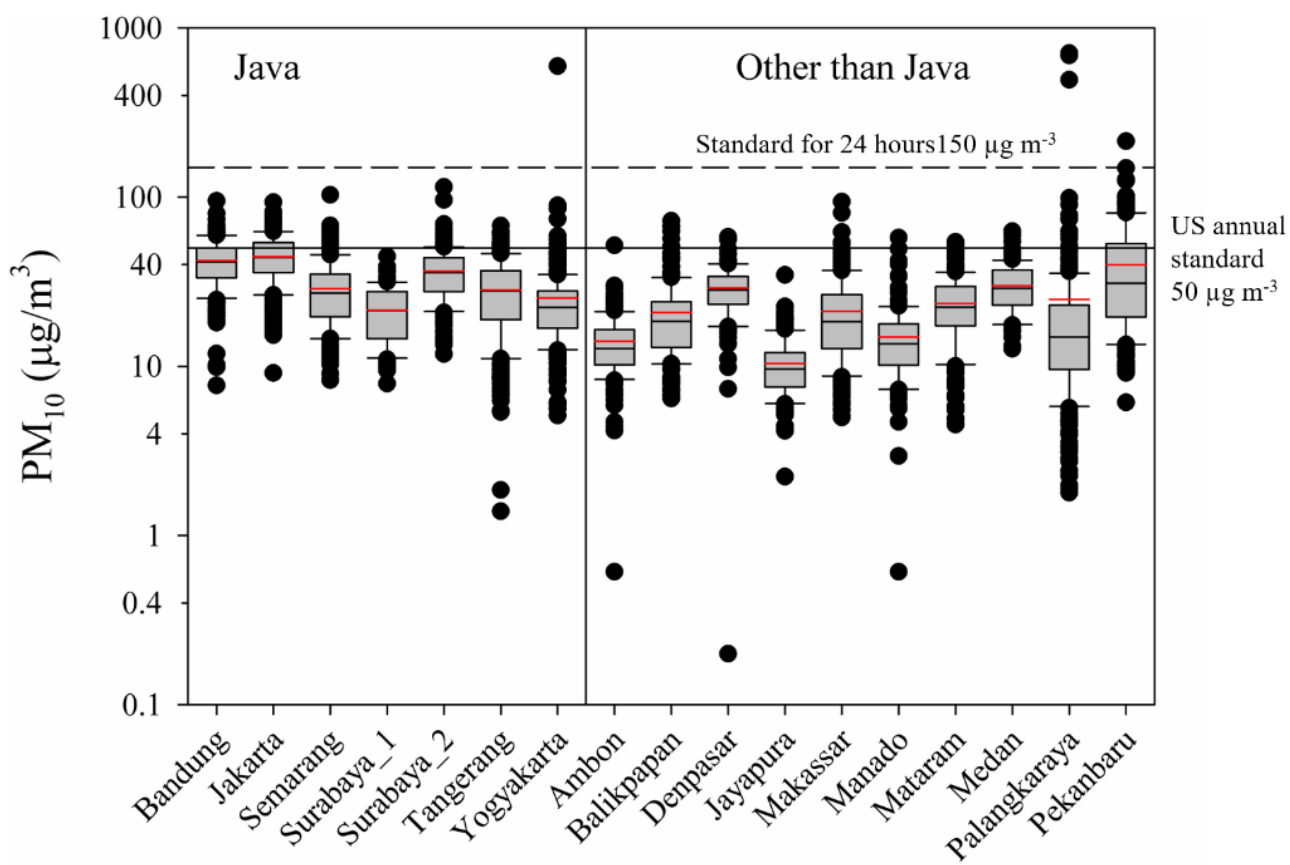

Fig. 3. Box-and-whisker plots of the $\mathrm{PM}_{10}$ distributions across Indonesia.

The annual average $\mathrm{PM}_{2.5}$ and $\mathrm{PM}_{10}$ values for all sites are provided in Tables 3 and 4, respectively. Box-and-whisker plots for $\mathrm{PM}_{2.5}$ and $\mathrm{PM}_{10}$ for each site over the measurement periods can be seen in Figs. S18 and S19, respectively. The National Ambient Air Quality Standard of Indonesia for annual average $\mathrm{PM}_{2.5}$ is $15 \mu \mathrm{g} \mathrm{m}^{-3}$, while the $24-\mathrm{h}$ standard is $65 \mu \mathrm{g} \mathrm{m}^{-3}$. For $\mathrm{PM}_{10}$, government regulation PP No. 41 of 1999 only set the standard for $24 \mathrm{~h}$ of $150 \mu \mathrm{g} \mathrm{m}^{-3}$.

Table 3 and Fig. S18 show that $\mathrm{PM}_{2.5}$ concentrations in Bandung had a slight upward trend from 2012 to 2017 likely due to an increase in population and heavy traffic in the urban center. The annual average $\mathrm{PM}_{2.5}$ has exceeded Indonesian standard. Based on data from the Central Statistics Agency of West Java, the 2017 population in the city of Bandung reached 2.497 million. Between 2012 to 2017, there was a significant increase in the number of motor vehicles, cars and motorbikes. The various programs undertaken to improve air quality in Bandung, especially for $\mathrm{PM}_{2.5}$, have succeeded in compensating for its dense population and increasing use of motorized vehicles. For $\mathrm{PM}_{10}$, as shown in Table 4 and Fig. S19, all $\mathrm{PM}_{10}$ concentrations in Bandung were below the Indonesian 24-h standard. 


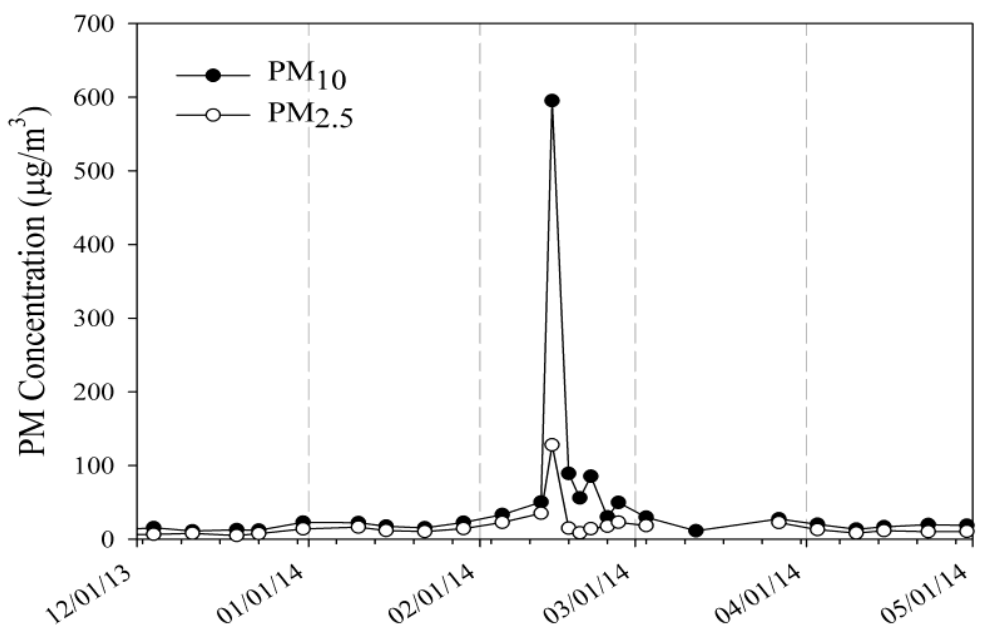

Fig. 4. Time series of $\mathrm{PM}_{2.5}$ concentrations in Yogyakarta.

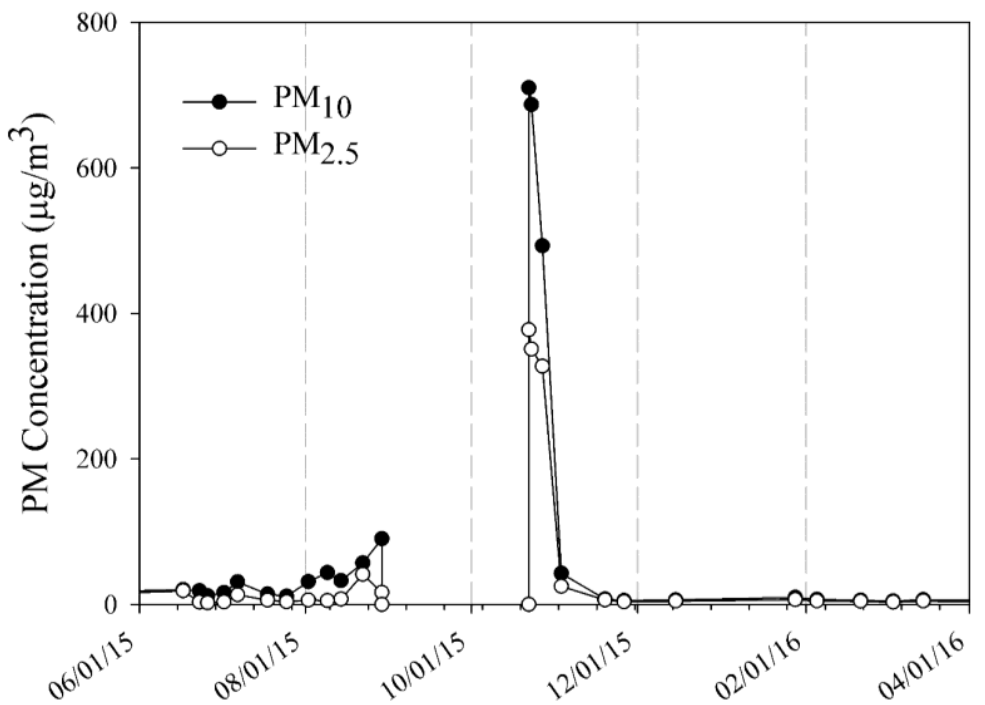

Fig. 5. Time series of $\mathrm{PM}_{2.5}$ and $\mathrm{PM}_{10}$ in Palangka Raya from 2015 to 2016.

The 8 years of monitoring in Jakarta (2010-2017) showed the average annual $\mathrm{PM}_{2.5}$ concentrations failed to meet Indonesian standard. Several programs have been implemented such as increasing the number and quality of mass transportation, requiring a minimum number of passengers in one car (three in one), implementing car-free days, and various other programs, but these efforts have not been able to reach the goal of bringing the annual average concentration of $\mathrm{PM}_{2.5}$ below the Indonesian standard. High use of motor vehicles and dense population that in 2017 reached 10.37 million are a major contributor to pollution in Jakarta. As the capital city of Indonesia, it is the center of government and business. Motorized vehicles in Jakarta are not only from local Jakarta but also from several cities around it. The commuters contribute significantly to the traffic density in Jakarta. The $\mathrm{PM}_{2.5}$ concentrations in 2017 as seen in Fig. S18 have a wide range. The $\mathrm{PM}_{10}$ concentrations for Jakarta were below the Indonesian standard as seen in Table 4 and Fig. S19.

The annual average $\mathrm{PM}_{2.5}$ values at Surabaya_1 and Surabaya_2 sites exceed Indonesian standards (Table 3 and
Fig. S18), except for the 2013 annual average at Surabaya_1. Surabaya_1 is located nearer to the urban centers, while Surabaya_2 is located on the border of Surabaya and Sidoarjo that has major industrial activity. Therefore, in general, the $\mathrm{PM}_{2.5}$ concentrations at Surabaya_2 tend to be higher than those at Surabaya_1. As the second-largest city after Jakarta, Surabaya had a population of 2.87 million in 2017. The number of cars and motorcycles reached 1 million and 14 million, respectively. The greater use of motor vehicles and dense population are a major factor for high pollution in Surabaya, as well as the contributions of industrial emissions around the city. The concentration of $\mathrm{PM}_{10}$ was below the Indonesian standard as shown in Table 4 and Fig. S19.

For Semarang, the annual average $\mathrm{PM}_{2.5}$ concentration over the 5 years of monitoring (2013-2017) failed to achieve the Indonesian standard as shown in Fig. S18. As the capital city of Central Java province, Semarang has an industrial area with various industries including electronics assembly, motor vehicles industry, and garment industry. Comprehensive research needs to be carried out to confirm whether these 
Table 3. Annual average for $\mathrm{PM}_{2.5}$ mass concentrations in the 16 Indonesian cities.

\begin{tabular}{|c|c|c|c|c|c|c|c|c|c|c|}
\hline \multirow{2}{*}{ No } & \multirow{2}{*}{ Island } & \multirow{2}{*}{ City } & \multicolumn{8}{|c|}{$\mathrm{PM}_{2.5}$ Concentration $\left(\mu \mathrm{g} \mathrm{m}^{-3}\right)$} \\
\hline & & & 2010 & 2011 & 2012 & 2013 & 2014 & 2015 & 2016 & 2017 \\
\hline 1 & Java & Bandung & & & $17 \pm 7$ & $14 \pm 5$ & $20 \pm 8$ & $21 \pm 6$ & $18 \pm 7$ & $19 \pm 10$ \\
\hline 2 & & Jakarta & $15 \pm 7$ & $17 \pm 7$ & $19 \pm 8$ & $17 \pm 7$ & $18 \pm 6$ & $16 \pm 5$ & $15 \pm 5$ & $19 \pm 12$ \\
\hline 3 & & Semarang & & & & $15 \pm 6$ & $16 \pm 9$ & $19 \pm 8$ & $18 \pm 6$ & $15 \pm 5$ \\
\hline \multirow[t]{2}{*}{4} & & Surabaya 1 & & & & & & $17 \pm 5$ & $13 \pm 6$ & $15 \pm 5$ \\
\hline & & Surabaya 2 & & & $20 \pm 5$ & $15 \pm 5$ & $17 \pm 4$ & $16 \pm 8$ & $15 \pm 4$ & $17 \pm 4$ \\
\hline 5 & & Tangerang & $14 \pm 7$ & $16 \pm 6$ & $12 \pm 5$ & $14 \pm 4$ & $19 \pm 7$ & $13 \pm 6$ & $13 \pm 6$ & $13 \pm 8$ \\
\hline 6 & & Yogyakarta $^{a}$ & $9 \pm 5$ & $10 \pm 3$ & $10 \pm 3$ & $11 \pm 4$ & $14 \pm 5^{a}$ & $12 \pm 7$ & $10 \pm 5$ & $10 \pm 4$ \\
\hline 7 & Outside & Ambon & & & & $7 \pm 2$ & $9 \pm 4$ & $9 \pm 4$ & $6 \pm 3$ & $7 \pm 4$ \\
\hline 8 & Java & Balikpapan $^{\mathrm{e}}$ & & & & $9 \pm 6$ & $6 \pm 3^{e}$ & $17 \pm 9^{e}$ & $9 \pm 3$ & $9 \pm 3$ \\
\hline 9 & & Denpasar & & & $15 \pm 3$ & $10 \pm 4$ & $14 \pm 5$ & & $13 \pm 6$ & $12 \pm 5$ \\
\hline 10 & & Jayapura & & & & $3 \pm 2$ & $5 \pm 3$ & $5 \pm 2$ & $4 \pm 1$ & $6 \pm 3$ \\
\hline 11 & & Makassar & & & $9 \pm 4$ & $7 \pm 3$ & $20 \pm 10$ & $14 \pm 7$ & $10 \pm 4$ & $10 \pm 4$ \\
\hline 12 & & Manado & & & & $6 \pm 3$ & $7 \pm 6$ & $6 \pm 5$ & $8 \pm 2$ & $6 \pm 2$ \\
\hline 13 & & Mataram $^{\mathrm{c}}$ & & & & $7 \pm 1$ & $14 \pm 4$ & $11 \pm 4$ & $11 \pm 5$ & $7 \pm 5^{c}$ \\
\hline 14 & & Medan & & & & & $7 \pm 7$ & & $10 \pm 6$ & $11 \pm 6$ \\
\hline 15 & & Palangka Raya ${ }^{\mathrm{b}}$ & & $9 \pm 5$ & $12 \pm 10$ & $7 \pm 7$ & $4 \pm 4$ & $8 \pm 9^{b}$ & $5 \pm 2$ & $7 \pm 2$ \\
\hline 16 & & Pekanbaru $^{\mathrm{d}}$ & & & $19 \pm 9$ & $18 \pm 9$ & $29 \pm 11^{\mathrm{d}}$ & $18 \pm 9$ & $8 \pm 6$ & $13 \pm 5$ \\
\hline
\end{tabular}

${ }^{a}$ Without sample collected on 14 February 2014 during the eruption of Mt. Kelud, average PM 2.5 in 2014 with volcanic eruption episodes was $16 \pm 18 \mu \mathrm{g} \mathrm{m}^{-3}$.

${ }^{\mathrm{b}}$ Without samples collected on 22-27 October 2015 when there was a large forest fire in Kalimantan, average $\mathrm{PM}_{2.5}$ in 2015 with forest fire episodes was $46 \pm 111 \mu \mathrm{g} \mathrm{m}^{-3}$.

${ }^{\mathrm{c}}$ In 2017, samples were collected on weekends (70\%) and workdays (30\%).

${ }^{\mathrm{d}}$ In 2014, samples were only collected for 3 months (January-March).

e In the 2014-2015 period, samples were only collected January-June 2014 and August-December 2015.

Table 4. Annual average for $\mathrm{PM}_{10}$ mass concentrations in the 16 Indonesian cities.

\begin{tabular}{|c|c|c|c|c|c|c|c|c|c|c|}
\hline \multirow{2}{*}{ No } & \multirow{2}{*}{ Island } & \multirow{2}{*}{ City } & \multicolumn{8}{|c|}{$\mathrm{PM}_{10}$ Concentration $\left(\mu \mathrm{g} \mathrm{m}^{-3}\right)$} \\
\hline & & & 2010 & 2011 & 2012 & 2013 & 2014 & 2015 & 2016 & 2017 \\
\hline 1 & Java & Bandung & & & $44 \pm 155$ & $39 \pm 11$ & $46 \pm 14$ & $47 \pm 12$ & $42 \pm 11$ & $38 \pm 14$ \\
\hline 2 & & Jakarta & $36 \pm 11$ & $42 \pm 11$ & $50 \pm 15$ & $39 \pm 13$ & $46 \pm 13$ & $51 \pm 12$ & $44 \pm 9$ & $50 \pm 16$ \\
\hline 3 & & Semarang & & & & $29 \pm 12$ & $28 \pm 14$ & $30 \pm 15$ & $32 \pm 12$ & $25 \pm 11$ \\
\hline 4 & & Surabaya 1 & & & & & & $26 \pm 6$ & $18 \pm 7$ & $23 \pm 8$ \\
\hline & & Surabaya 2 & & & $50 \pm 17$ & $29 \pm 9$ & $38 \pm 16$ & $37 \pm 12$ & $35 \pm 10$ & $38 \pm 9$ \\
\hline 5 & & Tangerang & $24 \pm 11$ & $31 \pm 13$ & $29 \pm 12$ & $32 \pm 11$ & $39 \pm 13$ & $28 \pm 12$ & $21 \pm 9$ & $22 \pm 11$ \\
\hline 6 & & Yogyakarta $^{\mathrm{a}}$ & $21 \pm 7$ & $21 \pm 8$ & $24 \pm 7$ & $22 \pm 5$ & $26 \pm 10^{\mathrm{a}}$ & $28 \pm 13$ & $21 \pm 6$ & $22 \pm 12$ \\
\hline 7 & Outside & Ambon & & & & $16 \pm 4$ & $15 \pm 6$ & $15 \pm 5$ & $15 \pm 4$ & $15 \pm 6$ \\
\hline 8 & Java & Balikpapan ${ }^{\mathrm{e}}$ & & & & $25 \pm 11^{\mathrm{e}}$ & $16 \pm 6^{e}$ & $41 \pm 15$ & $21 \pm 6$ & $14 \pm 4$ \\
\hline 9 & & Denpasar & & & $44 \pm 8$ & $24 \pm 7$ & $31 \pm 9$ & & $28 \pm 7$ & $29 \pm 7$ \\
\hline 10 & & Jayapura & & & & $10 \pm 4$ & $11 \pm 6$ & $11 \pm 4$ & $9 \pm 2$ & $12 \pm 3$ \\
\hline 11 & & Makassar & & & $26 \pm 10$ & $21 \pm 9$ & $28 \pm 14$ & $20 \pm 14$ & $14 \pm 5$ & $13 \pm 5$ \\
\hline 12 & & Manado & & & & $18 \pm 5$ & $15 \pm 9$ & $18 \pm 10$ & $14 \pm 4$ & $12 \pm 4$ \\
\hline 13 & & Mataram $^{\mathrm{c}}$ & & & & & $36 \pm 12$ & $24 \pm 9$ & $23 \pm 10$ & $19 \pm 6^{c}$ \\
\hline 14 & & Medan & & & & & $29 \pm 12$ & & $29 \pm 10$ & $32 \pm 9$ \\
\hline 15 & & Palangka Raya ${ }^{\mathrm{b}}$ & & $20 \pm 8$ & $27 \pm 19$ & $18 \pm 11$ & $9 \pm 9$ & $20 \pm 21^{b}$ & $11 \pm 5$ & $16 \pm 6$ \\
\hline 16 & & Pekanbaru $^{\mathrm{d}}$ & & & $50 \pm 32$ & $27 \pm 28$ & $74 \pm 30^{d}$ & $30 \pm 18$ & $21 \pm 9$ & $27 \pm 14$ \\
\hline
\end{tabular}

${ }^{a}$ Without sample collected on 14 February 2014 during the eruption of Mt. Kelud, average PM $_{10}$ in 2014 with volcanic eruption episodes was $41 \pm 82 \mu \mathrm{g} \mathrm{m}^{-3}$.

${ }^{\mathrm{b}}$ Without samples collected on 22-27 October 2015 when there was a large forest fire in Kalimantan, average $\mathrm{PM}_{10}$ in 2015 with forest fire episodes was $88 \pm 199 \mu \mathrm{g} \mathrm{m}^{-3}$.

${ }^{\mathrm{c}}$ In 2017, samples were collected on weekends (70\%) and workdays (30\%).

d In 2014, samples were only collected for 3 months (January-March).

e In the 2014-2015 period, samples were only collected January-June 2014 and August-December 2015. 
industrial activities contributes significantly to the air quality in Semarang. The daily average $\mathrm{PM}_{10}$ is below the Indonesian standard.

Monitoring over 8 years in Tangerang and Yogyakarta (Table 3 and Fig. S18) shows that the annual average PM $_{2.5}$ meets the Indonesian standard except for Tangerang in 2011 and 2014. Although the annual average met the Indonesian standards, the 8-year annual average for both sites exceeds the World Health Organization (WHO) annual standard for $\mathrm{PM}_{2.5}\left(10 \mu \mathrm{g} \mathrm{m}^{-3}\right)$. It should be noted that the Gent sampler underestimates $\mathrm{PM}_{2.5}$ mass concentrations because the $50 \%$ collection efficiency point is closer to $2.2 \mu \mathrm{m}$ than $2.5 \mu \mathrm{m}$ (Hopke et al., 1997). Sampling site in Tangerang is located in the area of the Science and Technology Research Center (PUSPIPTEK) which is a very wide area of 660 ha and has a very large park with trees. Previous studies have shown that southern Tangerang has serious air pollution problem, mainly related to high $\mathrm{Pb}$ concentration in $\mathrm{PM}_{2.5}$ which are very dangerous for the health of the surrounding community especially for children (Santoso et al., 2011). Therefore, air quality monitoring in Tangerang needs to be done continuously to ensure the effectiveness of the programs undertaken to improve its air quality.

For Yogyakarta, the air quality is better than other sites in Java. There are fewer industrial activities in Yogyakarta than in any other site on Java. However, there are several episodes of volcanic eruptions located around Yogyakarta causing high concentrations of both $\mathrm{PM}_{2.5}$ and $\mathrm{PM}_{10}$. As seen in Figs. S18 and $\mathrm{S} 19$, the high concentration of both $\mathrm{PM}_{2.5}$ and $\mathrm{PM}_{10}$ in 2014 were the results of the Mount Kelud eruption on 14 February 2014.

For the sites in Java, the results obtained from this study indicated that most cities failed to meet the Indonesian annual ambient air quality standard for $\mathrm{PM}_{2.5}$. Several mitigation programs have been implemented, but these efforts have not been able to significantly reduce the PM concentration in these cities likely due to a rapid growth of industry, population, and motor vehicle usage. Although the daily average for $\mathrm{PM}_{10}$ as shown in Table 4 and Fig. S19 is lower than Indonesian daily standard, it substantially exceeded WHO annual average standard $\left(20 \mu \mathrm{g} \mathrm{m}^{-3}\right)$. Compared to other air quality research on Asia, the results of $\mathrm{PM}_{2.5}$ on sampling sites inside Java, Indonesia, with annual average ranged from 9 to $20 \mu \mathrm{g} \mathrm{m}^{-3}$, was lower than the annual concentration of $\mathrm{PM}_{2.5}$ measured in Selangor, Malaysia $\left(25.13 \mu \mathrm{g} \mathrm{m}^{-3}\right)$, by Khan et al. (2016); Petaling Jaya, Kuala Lumpur $\left(26.85 \mu \mathrm{g} \mathrm{m}^{-3}\right)$, by Rahman et al. (2011); Dhaka $\left(26.22 \mu \mathrm{g} \mathrm{m}^{-3}\right)$ by Begum et al. (2010), while compared to study in urban and suburban area in Thailand, the value in this study was similar with the mean of fine particulate in Bang Khen and Khlong Ha, Thailand (13.4 and $18.1 \mu \mathrm{g} \mathrm{m}^{-3}$, respectively), by Chueinta et al. (2000). Kim Oanh (2006) reported the comparative study conducted in Bandung (45.5 $\left.\mu \mathrm{g} \mathrm{m}^{-3}\right)$, Bangkok $\left(34 \mu \mathrm{g} \mathrm{m}^{-3}\right)$, Beijing $\left(136 \mu \mathrm{g} \mathrm{m}^{-3}\right)$, Chennai $\left(44 \mu \mathrm{g} \mathrm{m}^{-3}\right)$, Hanoi $\left(78.5 \mu \mathrm{g} \mathrm{m}^{-3}\right)$ and Manila $\left(43.5 \mu \mathrm{g} \mathrm{m}^{-3}\right.$ ) showed consistently higher $\mathrm{PM}_{2.5}$ pollution in the Southeast and South Asian cities as compared to this study (Kim Oanh et al., 2006).

The annual average $\mathrm{PM}_{2.5}$ and $\mathrm{PM}_{10}$ for the sites outside of Java (Ambon, Balikpapan, Denpasar, Jayapura, Makassar,
Manado, Mataram, Medan, Palangka Raya, and Pekanbaru) are provided in Tables 3-4 and Figs. S18-S19. The time series plots for these locations are presented in Figs. S8-S17. The annual average $\mathrm{PM}_{2.5}$ in these cities were lower than the Indonesian standard except in Pekanbaru.

The annual average $\mathrm{PM}_{2.5}$ for Ambon, Jayapura and Manado meet both Indonesian and WHO standards. Some $\mathrm{PM}_{2.5}$ concentrations in Manado were high in 2014, 2015, and 2017 because of New Year's celebrations and the effects of volcanic eruptions such as Mount Lokon and Mount Soputan. For Mataram, the annual average $\mathrm{PM}_{2.5}$ in 2017 is significantly different compared to the previous year, where most of the samplings were done on weekends (70\%) due to technical obstacles in the field. Some high $\mathrm{PM}_{2.5}$ concentrations in Medan in 2014, 2016 and 2017 resulted from the extended eruption of Mount Sinabung located $80 \mathrm{~km}$ from the city. Sinabung is one of the active volcanoes in Sumatra, which straddles the Pacific Ring of Fire. Although Bali is famous for its tourism, the air quality in Denpasar still meets Indonesian standards for annual average of $\mathrm{PM}_{2.5}$. Some high $\mathrm{PM}_{2.5}$ concentrations in 2016 were due to the eruption of Mount Rinjani in September 2016 with volcanic ash eruptions reaching $2000 \mathrm{~m}$. Table 3 and Fig. S18 show that the annual average $\mathrm{PM}_{2.5}$ at the Balikpapan site in 2015 was higher compared to other years because due to technical problems, sampling was only conducted from August to December 2015. The annual average of $\mathrm{PM}_{2.5}$ in Makassar met the Indonesian standards except in 2014. High $\mathrm{PM}_{2.5}$ concentrations occurred in July to November 2014 and might be related to a long dry season. Pekanbaru and Palangka Raya are the cities most affected by forest fires episodes that occurred on the islands of Sumatra and Kalimantan. In 2015, a major forest fires episode occurred such that the haze affected not only air quality in Indonesia especially Sumatra and Kalimantan, but also spread across neighboring countries and affected their air quality. After the 2015 forest fires episode, there were decreasing $\mathrm{PM}_{2.5}$ concentrations due to the intensive law enforcement and policy restricting land clearing by forest burning. Compared to other locations outside Java, the annual average of $\mathrm{PM}_{2.5}$ in Pekanbaru was the highest. Pekanbaru is the capital city of Riau, the largest economic center in the eastern part of Sumatra island, and has a high growth rate of migration and urbanization. The economy in Pekanbaru is highly dependent on the oil industry. Most of Indonesia's petroleum is produced in Riau. Increased coal combustion, increased populations, and use of more motor vehicles might also be factors of high pollution in addition to the forest fires.

From the $\mathrm{PM}_{2.5}$ mass concentration results, the air quality outside of Java was noticeably better than on the island of Java, where there are denser population and more intensive industrial activities. Although Indonesia has more than 17,000 islands, more than $50 \%$ of the 260 million inhabitants live on Java. Although the air quality outside Java was generally good, some locations were vulnerable to forest fire problems that occur regularly and occasional volcanos.

\section{Black Carbon $(B C)$}

Average $\mathrm{BC}$ concentrations for the sites on Java ranged from 2.38 to $3.55 \mu \mathrm{g} \mathrm{m}^{-3}$, with average percentages of $\mathrm{BC}$ 
in $\mathrm{PM}_{2.5}$ at these sampling sites were 19.6-22.6\%. While for the sites outside Java, the averages of BC concentrations were $0.66-2.78 \mu \mathrm{g} \mathrm{m}^{-3}$. The average percentages of $\mathrm{BC}$ in $\mathrm{PM}_{2.5}$ at these sampling sites were 15.1-26.0\% (Table 2). The average $\mathrm{BC}$ fraction of $\mathrm{PM}_{2.5}$ ranged from $15 \%$ to $26 \%$ indicating that $\mathrm{BC}$ was a major component of the $\mathrm{PM}_{2.5}$. It is likely associated with traffic emissions and biomass burning (Santoso et al., 2013b). BC concentrations at the Java island sites (Bandung, Jakarta, Semarang and Surabaya) were higher than sites outside Java. For Denpasar compared to other sites outside of Java, high BC concentrations were likely a result of burning incense and other biomass burning. While for Makassar, the highest BC concentrations were likely contributed from biomass burning (Sattar et al., 2014).

BC sources in Bandung were previously studied by Santoso et al. (2008) and showed that the most important BC source was biomass burning. In Tangerang, Santoso et al. (2011) reported that $\mathrm{BC}$ originated from diesel vehicles and biomass burning mixed with road dust. For Jakarta, the BC sources were attributed to motor vehicles since the sampling site in Jakarta was located near one of the busiest arterial roads (Santoso et al., 2013a). For Yogyakarta, Semarang, and Surabaya, the sources of $\mathrm{BC}$ concentrations are poorly known, but in general, black carbon was likely contributed by biomass burning and motor vehicles. There is a contribution from open burning that is often still used by farmers in Indonesia as described by Permadi and Kim Oanh (2013). The box-and-whisker plot of black carbon concentrations at these sites is shown in Fig. 6. The average BC shown in Fig. 6 is lower than the results reported from the Philippines, Bangladesh, and Sri Lanka (Atanacio et al., 2016). The annual average of BC in each site is shown in Fig. S20.

\section{Elemental Concentrations}

The distributions for the elemental concentrations of $\mathrm{Si}$, $\mathrm{S}, \mathrm{K}, \mathrm{Fe}, \mathrm{Zn}$, and $\mathrm{Pb}$ in $\mathrm{PM}_{2.5}$ measured at the 17 sites are shown in Figs. 7-12. The time series for these major chemical species for each site are presented in Figs. S1-S17. There are several samples with high $\mathrm{Si}$ concentrations especially at the Yogyakarta site (Figs. 7 and S7). The highest $\mathrm{Si}$ concentrations in Yogyakarta were observed in the samples collected during the eruption episode as shown in the time series plot for Yogyakarta (Fig. S7). The highest concentration of $\mathrm{Si}$ was $13.8 \mu \mathrm{g} \mathrm{m}^{-3}, 130$ times higher than average values in the normal condition $\left(0.105 \mu \mathrm{g} \mathrm{m}^{-3}\right)$. Kelud erupted on 14 February 2014 at 22:50 Western Indonesian Time (UTC + 7). The eruption spread volcanic ash over a large portion of Java including Central Java and Yogyakarta. The ash reached as far as $240 \mathrm{~km}$ west of volcano into the western region of Java by the afternoon of 14 February where traces of volcanic ash were found in Bandung, Yogyakarta and surrounding areas (Kristiansen $e t$ al., 2015; Lestiani et al., 2018). The high silica concentrations may represent a human health threat if the silica is in crystalline form. Crystalline silica is known to cause silicosis, a disabling and potentially fatal lung disease typically found in miners and quarry workers exposed to high concentrations of siliceous dust over long periods (Baxter and Horwell, 2015).

Fig. 7 shows that high $\mathrm{Si}$ concentrations occurred from several events including the volcanic eruption and local construction activities. During the sampling period, there were several volcanic eruptions in Indonesia including Mount Sinabung in Medan (Kusmartini et al., 2017), Mount Lokon in Manado, Mount Kelud in Central Java, and Mount Agung in Bali. Indonesian geology is dominated by volcanoes formed by a subduction zone between the Eurasian plate and the Indo-Australian plate. As part of the Pacific Ring of Fire, Indonesia has more than 100 active volcanoes and millions of people live in danger zones. It has been suggested that earthquakes and tsunamis can trigger eruptions and vice versa (Mutaqin et al., 2019). The recent eruption of Krakatau triggered a tsunami in the Sunda Strait in December 2018 (European Commission, 2018).

The average sulfur concentrations in the 16 cities varied

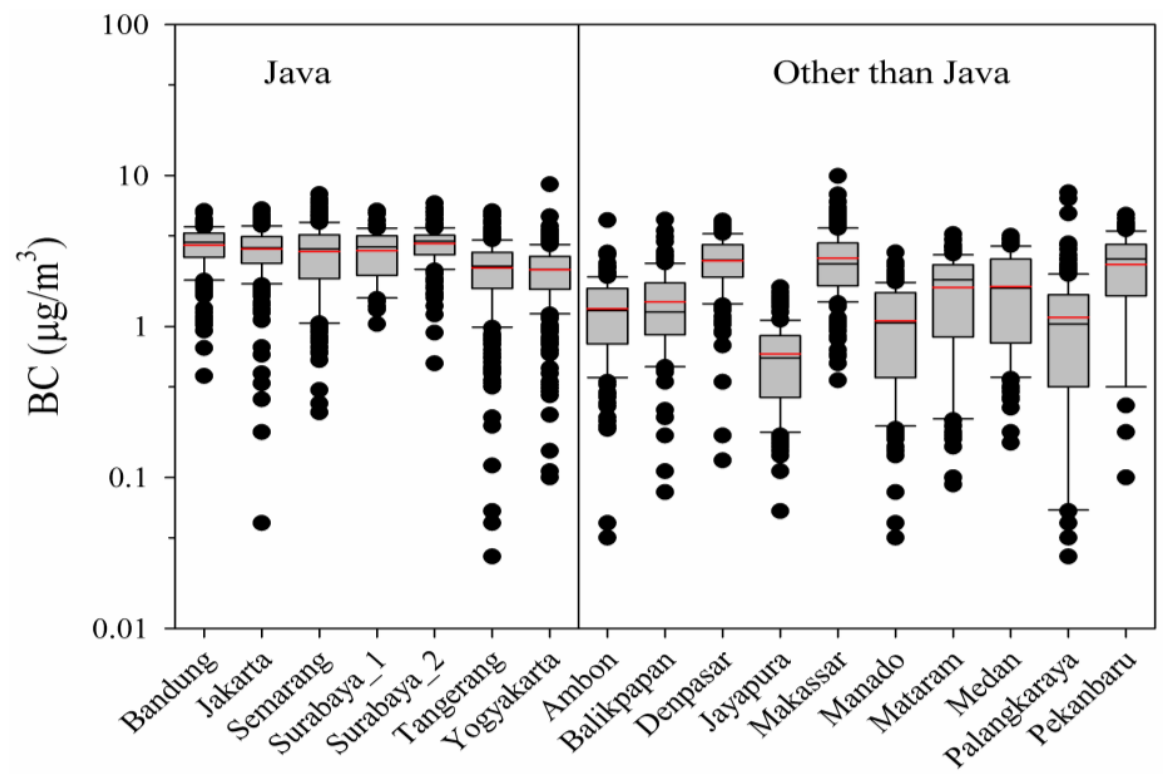

Fig. 6. The box-and-whisker plot for $\mathrm{BC}$ concentrations measured in the 16 cities in Indonesia. 


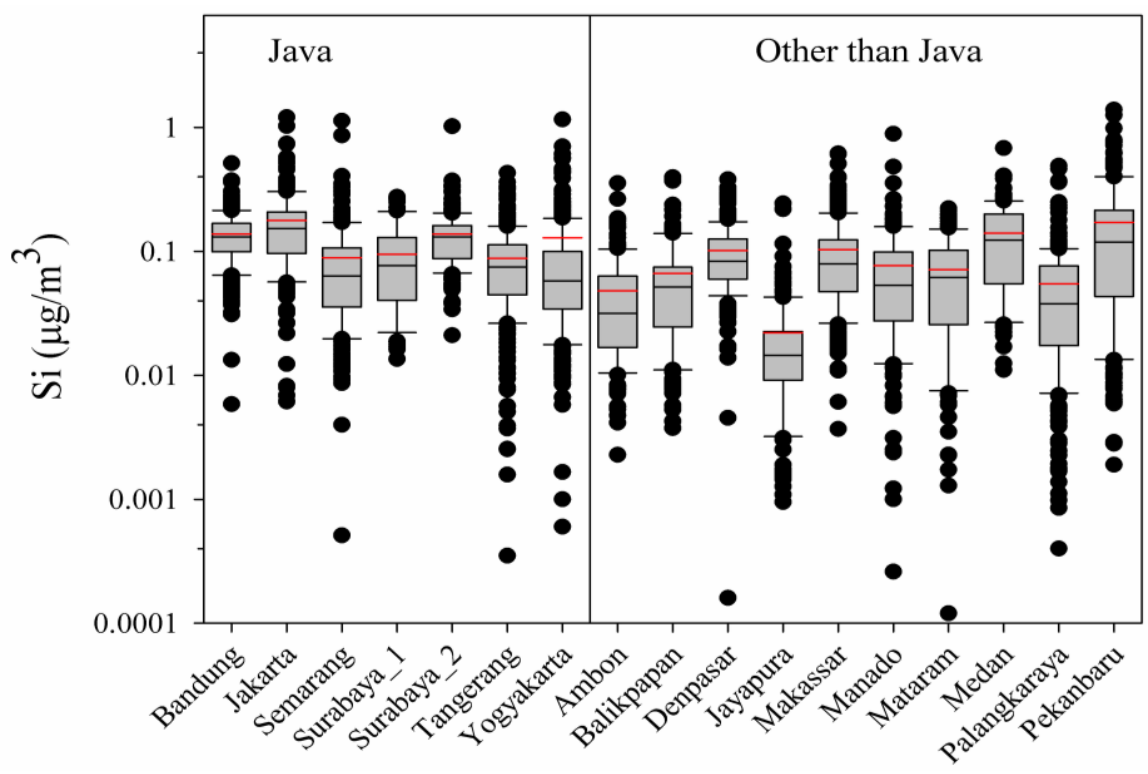

Fig. 7. The box-and-whisker plot of Si concentrations in $\mathrm{PM}_{2.5}$ at the 16 cities in Indonesia.

with the highest average of $1061 \mathrm{ng} \mathrm{m}^{-3}$ (Fig. 8), which was lower than the value of average sulfur in Petaling Jaya (1935 $\mathrm{ng} \mathrm{m}^{-3}$ ) (Rahman et al., 2011). These concentrations are likely the result of high sulfur concentrations in motor vehicle fuels since there is more than $2000 \mathrm{ppm} \mathrm{S}$ in diesel fuel in 2007 (Haryanto, 2018). Thus, locally formed sulfate can condense on the surface of the existing particles. Among these cities, Bandung has the highest sulfur average $\left(1061 \mathrm{ng} \mathrm{m}^{-3}\right)$ which was similar with Dakha (1200 $\mathrm{ng} \mathrm{m}^{-3}$ ) (Begum et al., 2010). These concentrations are likely the result of high sulfur contributions from the nearby volcano, Tangkuban Perahu, which is $30 \mathrm{~km}$ north of Bandung (Santoso et al., 2008; Kurniawati et al., 2019).

The high S concentration in Palangka Raya and Pekanbaru were likely from the peat forest fires that occurred in Kalimantan and Sumatra during the study period. Peat is the first step in geological formation in coal formation. Therefore, during a peat fire, various elements including sulfur and some heavy metals are emitted. Forest fires mostly occur during the dry season (June-September). They represent a problem in Indonesia every year especially in Sumatra and Kalimantan that have very large peatlands. The high concentration of sulfur at Palangka Raya comes from samples collected in October 2015 during the forest fire events as shown in Fig. S16 with $\mathrm{PM}_{2.5}$ values up to $400 \mu \mathrm{g} \mathrm{m}^{-3}$. The haze episode resulting from peat fires in Sumatra and Kalimantan had severe implications for human health (Betha et al., 2013).

During October 2015 when there was a forest fire in Palangka Raya, three samples were obtained that had very high $\mathrm{PM}_{2.5}$ concentrations, reaching 377,350 , and $327 \mu \mathrm{g} \mathrm{m}^{-3}$. $\mathrm{S}$ and $\mathrm{K}$ concentrations in the three samples were $12.7,11.4$, $2.7 \mu \mathrm{g} \mathrm{m}^{-3}$ and $0.40,0.42,0.29 \mathrm{~g} \mathrm{~m}^{-3}$, respectively (Fig. S16). The $\mathrm{S} / \mathrm{K}$ ratios were 31,27 and 9 . From these results it can be shown that the $\mathrm{S} / \mathrm{K}$ ratio at $\mathrm{PM}_{2.5}$ obtained from forest fires in Palangka Raya, Kalimantan, is very high, in the range 9-31. Similar results were obtained by Ikegami et al. (2001) who conducted an analysis of haze particle $(0.15-$
$3 \mu \mathrm{m}$ ) from Kalimantan that had an $\mathrm{S} / \mathrm{K}$ ratio of $9-18$. This result is very different from the results of forest fires in northern Australia with an $\mathrm{S} / \mathrm{K}$ ratio in the range 2-4. Low temperature fires $\left(<500^{\circ} \mathrm{C}\right)$ that would be associated with subterranean fires would lead to the formation of $\mathrm{SO}_{3}$ rather than SO2 (Cullis and Mulcahy, 1972). The high S/K ratio is estimated to originate from the combustion of forest biomass and the sulfur evolved from the combustion of peat below the ground.

Fig. 9 shows that $\mathrm{Pb}$ concentrations in Surabaya and Tangerang were significantly higher compared to the other cities. The time series of $\mathrm{Pb}$ concentration in Surabaya_1, Surabaya_2 and Tangerang are shown in Figs. S4, S5 and S6, respectively. The lead concentrations in Surabaya are the highest for all of the monitored cities. The measured maximum $\mathrm{Pb}$ concentration in Surabaya_1, Surabaya_2 and Tangerang sites were $0.73,2.7$ and $2.3 \mu \mathrm{g} \mathrm{m}^{-3}$, respectively. The Surabaya_2 and Tangerang sites exceeded the 24-h National Ambient Air Quality Standard of Indonesia for lead in total suspended particulate matter of $2 \mu \mathrm{g} \mathrm{m}^{-3}$ (Santoso et $a l ., 2019)$. The average lead concentrations in Surabaya_1, Surabaya_2 and Tangerang during this study period were $0.13,0.33$ and $0.22 \mu \mathrm{g} \mathrm{m}^{-3}$, respectively. These values were much higher compared to other cities in Asian countries (Hopke et al., 2008), and Surabaya_2 and Tangerang sites exceed the U.S. ambient air quality standard of $0.15 \mu \mathrm{g} \mathrm{m}^{-3}$. Begum et al. (2008) reported that in Bangladesh, the yearly average $\mathrm{Pb}$ in the air has increased slowly, and it may come from battery recycling and other industries. High $\mathrm{Pb}$ may also come from a galvanized plant which in the manufacturing process adds $\mathrm{Pb}$ to improve its reflectance properties (Begum and Hopke, 2019).

Studies of the high $\mathrm{Pb}$ concentrations in Tangerang were conducted previously in 2008. The source of lead in $\mathrm{PM}_{2.5}$ was identified to be associated with a lead battery recycling and bar production facility (Santoso et al., 2011). The results obtained in the present study showed that the average level 


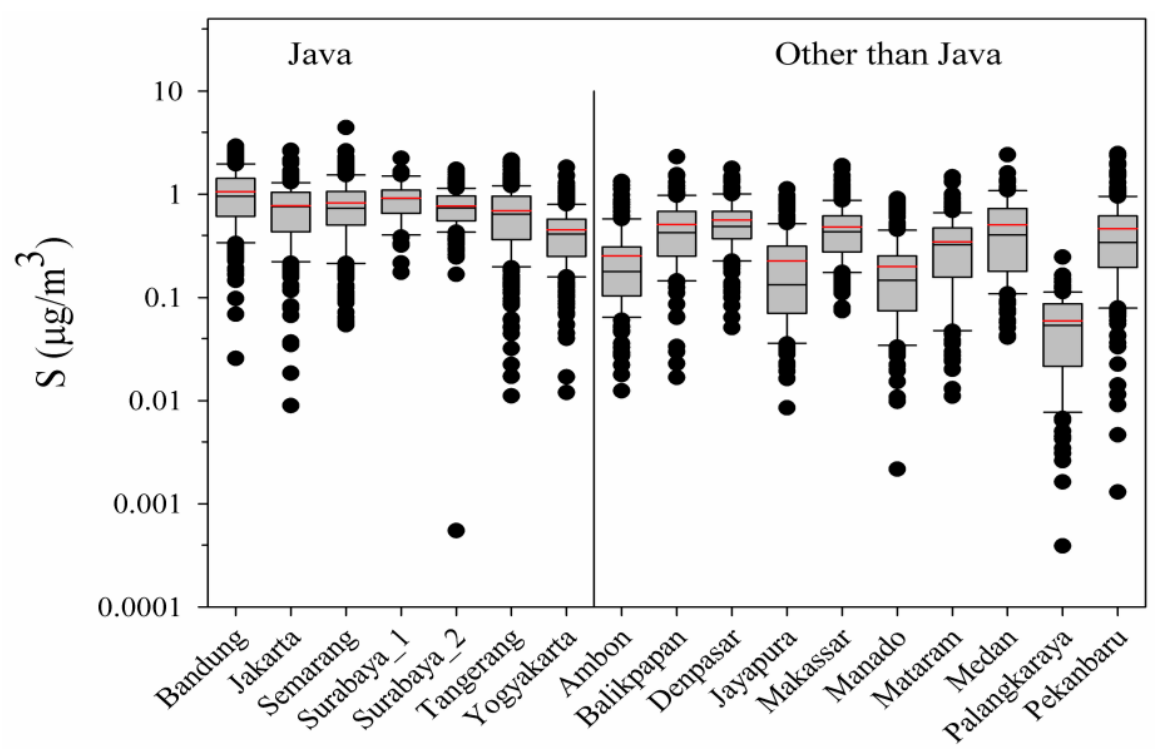

Fig. 8. The box-and-whisker plot of $\mathrm{S}$ concentrations in $\mathrm{PM}_{2.5}$ at the 16 cities in Indonesia.

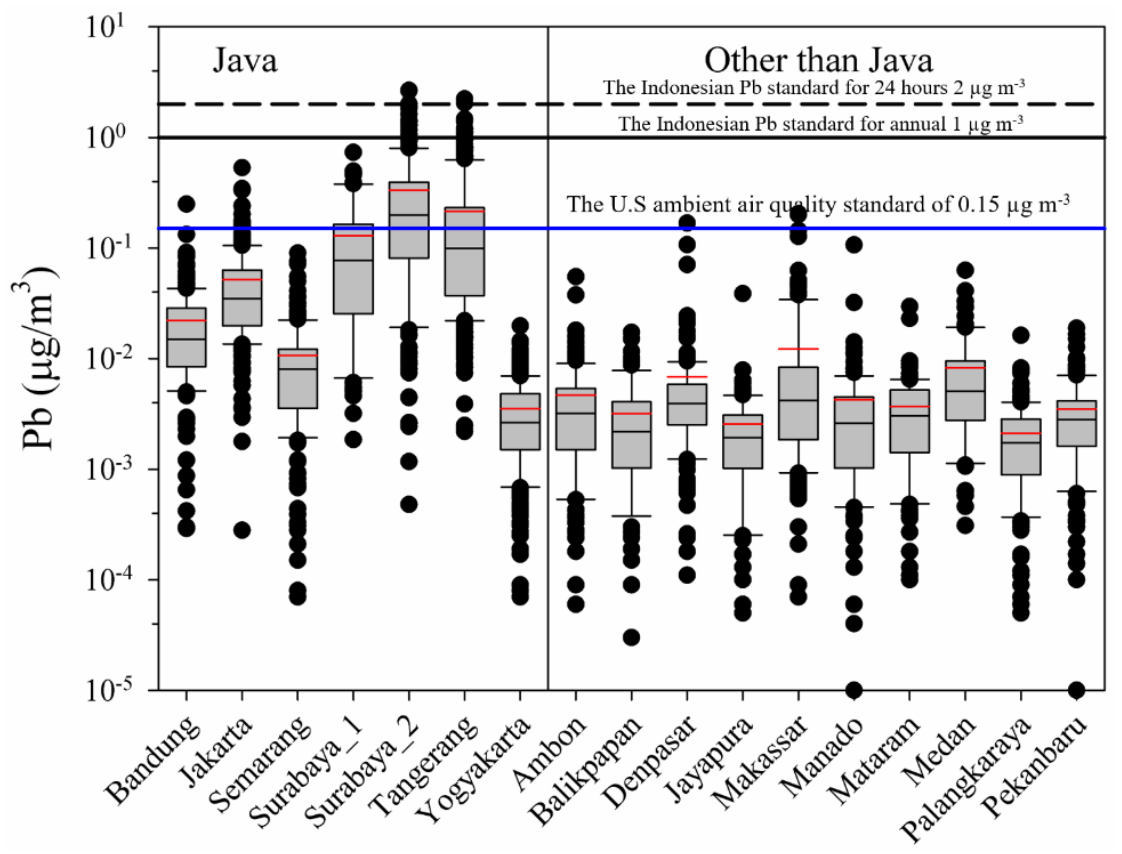

Fig. 9. The box-and-whisker plot of $\mathrm{Pb}$ concentrations in $\mathrm{PM}_{2.5}$ at the 16 cities in Indonesia.

of lead in $\mathrm{PM}_{2.5}$ collected during this study in Tangerang was 9.7, 4.2, 61 and 20 times higher than other sites in Java (Bandung, Jakarta, Yogyakarta, and Semarang, respectively). While compared to sites outside Java, the $\mathrm{Pb}$ concentrations in Tangerang were 40, 84, and 101 times higher than Ambon, Jayapura and Palangka Raya, respectively. The high level of $\mathrm{Pb}$ in airborne particulate matter in Tangerang has also affected the lead concentrations (9-11 times higher than the control area) in the soil around the Tangerang lead smelting area (Adventini et al., 2017). These findings strongly suggest the need for action to avoid adverse human health impacts and related economic impacts related to emissions from this facility. Lead pollution is very dangerous to the environment and health especially for children because it can cause mental retardation (Sharma et al., 2011; Karrari et al., 2012). Action needs to be initiated by the local government and Ministry of Environment and Forestry to address this problem.

Fig. 10 shows that high concentrations of $\mathrm{Zn}$ were found in several cities. Zn was likely emitted by motor vehicles and industrial activities. Two-stroke motor vehicles use oil containing additives that include zinc compounds to increase its lubricating capability. $\mathrm{Zn}$ is then released when the oil is burnt along with the gasoline. Zinc is also emitted from industrial activities such as non-ferrous metal smelting, galvanizing operations, and municipal solid waste incineration 


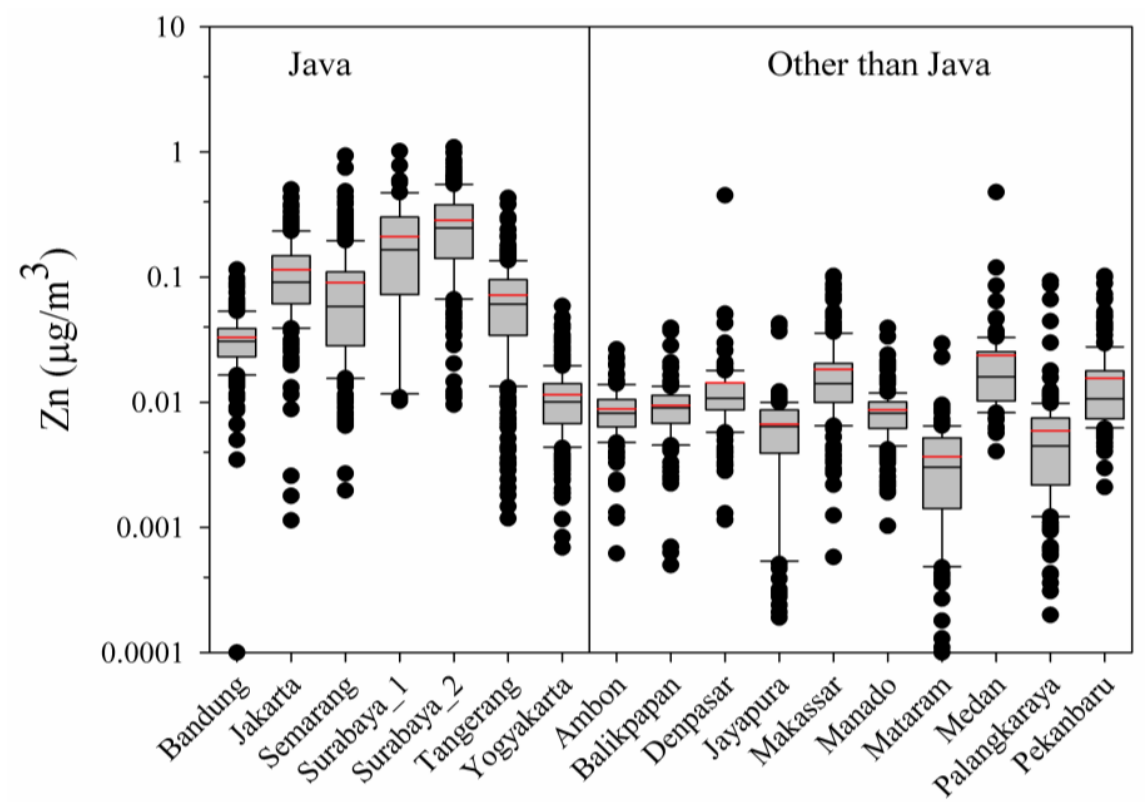

Fig. 10. The box-and-whisker plot of $\mathrm{Zn}$ concentrations in $\mathrm{PM}_{2.5}$ at the 16 cities in Indonesia.

(Hopke et al., 2008). The high concentrations of $\mathrm{Zn}$ in Surabaya, Semarang, and Jakarta with average concentrations of 285,91 and $114 \mathrm{ng} \mathrm{m}^{-3}$, respectively, were lower than the value in Selangor (389.3 $\left.\mathrm{ng} \mathrm{m}^{-3}\right)$, but higher compared to reported value in Petaling Jaya $\left(39 \mathrm{ng} \mathrm{m}^{-3}\right.$ ) (Rahman et al., 2011; Khan et al., 2016). The concentration of $\mathrm{Zn}$ in Surabaya was similar with Dhaka $\left(335 \mathrm{ng} \mathrm{m}^{-3}\right)$ which has the main sources of $\mathrm{Zn}$ from diesel emission and coal power plant (Begum et al., 2010). The high concentrations of $\mathrm{Zn}$ in Surabaya, Semarang, and Jakarta are estimated to be the result of contributions from multiple industrial activities in these cities including the galvanizing process in the industrial area around the sampling location. Source identification needs to be done to better estimate the impacts of these sources. The NAT method is generally only able to characterize $50 \%$ of the total mass of particulates, so to improve understanding of sources of pollutants, it is recommended that further research be able to combine the NAT method with other methods.

Fig. 11 shows the $\mathrm{Fe}$ concentration distributions. The results showed high concentrations of $\mathrm{Fe}$ in Surabaya and Jakarta. Sources likely include industrial activities, extensive infrastructure construction across the city including highways and mass transit lines. Yogyakarta showed its highest values in the samples collected during the eruption of Kelud in February 2014 (Fig. S7). A study by Khan et al. (2016) reported the average concentrations of Fe was $3052 \mathrm{ng} \mathrm{m}^{-3}$, which is much higher than this study in Java sampling sites in Jakarta, Semarang and Surabaya (108, 47, and $143 \mathrm{ng} \mathrm{m}^{-3}$, respectively). But compared to other study by Rahman (2011), Begum et al. (2010) and Chueinta (2000), the value of Fe is in the same range in Petaling Jaya $\left(112 \mathrm{ng} \mathrm{m}^{-3}\right)$, Dhaka $\left(195 \mathrm{ng} \mathrm{m}^{-3}\right)$ and Thailand $\left(26.5-70.2 \mathrm{ng} \mathrm{m}^{-3}\right)$, respectively.

Fig. 12 presents the distributions of $\mathrm{K}$ showing that some cities had substantially higher concentrations of $\mathrm{K}$ compared to the other sites. $\mathrm{K}$ is a tracer for biomass combustion. The high concentrations of $\mathrm{K}$ in Pekanbaru and Palangka Raya were related to the forest fire events that occur frequently in these locations. The high $\mathrm{K}$ concentrations in Denpasar is attributed to burning incense that is often used as part of religious ceremonies.

\section{CONCLUSIONS}

The National Ambient Air Quality Standards of Indonesia, which were last evaluated in 1999, are presently being reviewed for potential revision. This study, which provides current data about air quality in the nation, offers valuable input for the new regulatory standards. The average annual $\mathrm{PM}_{2.5}$ concentrations at most of the urban sites on Java exceeded the national standard. The cities outside of Java, however, except for Pekanbaru and Palangka Raya, were in compliance with the standard. The percentage of BC in the $\mathrm{PM}_{2.5}$ averaged between $15 \%$ and $26 \%$ (a significant fraction), and higher concentrations of $\mathrm{BC}$, which is associated with traffic emission and biomass burning, were found on Java as well as in Denpasar and Makassar. Additionally, the concentrations of the major elements in the $\mathrm{PM}_{2.5}$, viz., $\mathrm{Si}, \mathrm{S}, \mathrm{K}, \mathrm{Fe}, \mathrm{Zn}$, and $\mathrm{Pb}$, varied between the sites, and all of the locations exhibiting elevated levels of Si were likely affected by road dust and volcanic emissions. Owing to forest and peat fires, Palangka Raya displayed the maximum concentrations of sulfur, and high values for this element were also observed in Bandung, where relatively continual gaseous emission from Mount Tangkuban Perahu and the combustion of high sulfur vehicular fuel were contributing factors. Finally, higher concentrations of heavy metals, viz., Fe, $\mathrm{Zn}$, and $\mathrm{Pb}$, were measured in Surabaya than the other cities. The concentration of $\mathrm{Pb}$, in particular, was 10-100 times higher in Surabaya and Tangerang. Considering the adverse health effects of this element, appropriate actions must be taken to reduce exposure in these areas. 


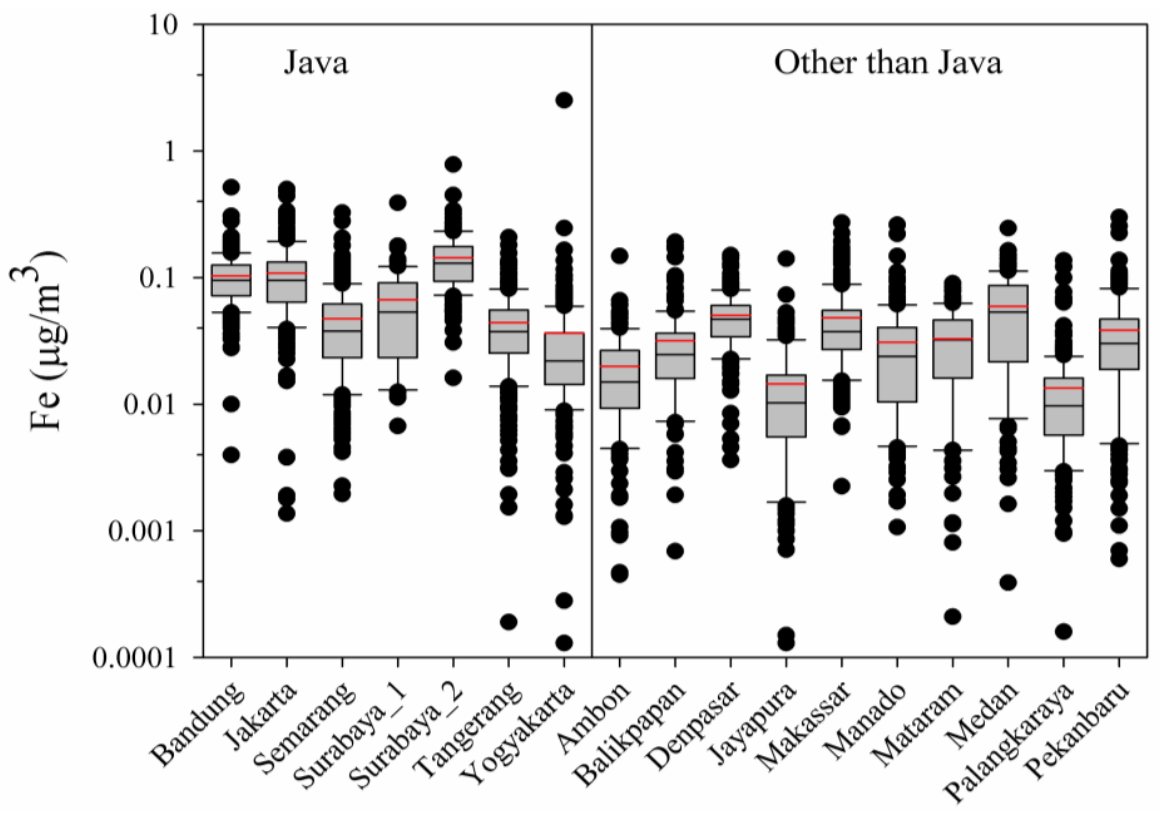

Fig. 11. The box-and-whisker plot of Fe concentrations in $\mathrm{PM}_{2.5}$ at the 16 cities in Indonesia.

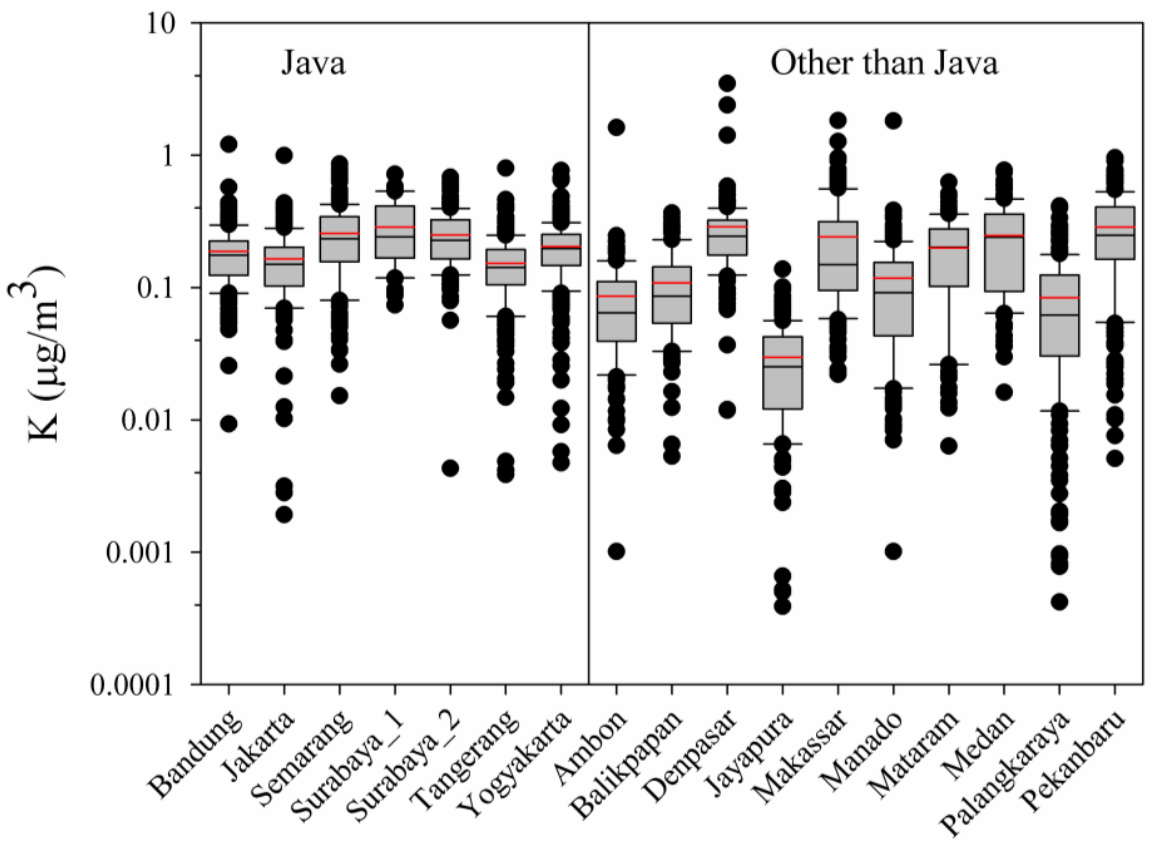

Fig. 12. The box-and-whisker plot of $\mathrm{K}$ concentrations in $\mathrm{PM}_{2.5}$ at the 16 cities in Indonesia.

\section{ACKNOWLEDGEMENT}

The authors acknowledge the National Nuclear Energy Agency for the financial support throughout this work. The authors also gratefully acknowledge to all the staff members in Radiometry Analytical Techniques group in Center for Applied Nuclear Science and Technology (BATAN) and Center for Research and Development of Laboratory and Environmental Quality, Ministry of Environment and Forestry, for their technical assistance. Besides that, the authors also thank the International Atomic Energy Agency (IAEA) through the RCA RAS7029 and TC INS7007 projects.

\section{APPENDIX A. SUPPLEMENTARY DATA}

Supplementary data S1-S17 contain time series mass distribution and major species concentration of fine particulate at 17 sites in Indonesia, while S18-S20 contain box plot annual concentration of $\mathrm{PM}_{2.5}, \mathrm{PM}_{10}$ and $\mathrm{BC}$, respectively.

Supplementary data associated with this article can be found in the online version at https://doi.org/10.4209/aaqr.2 019.09.0451 


\section{REFERENCES}

Adventini, N., Santoso, M., Lestiani, D. D., Syahfitri, W. Y. N. and Rixson, L. (2017). Lead identification in soil surrounding a used lead acid battery smelter area in Banten, Indonesia. J. Phys. Conf. Ser. 860: 012006. https://doi.org/10.1088/1742-6596/860/1/012006

Atanacio, A.J., Cohen, D.D., Begum, B.A., Ni, B., Pandit, G.G., Sahu, S.K., Santoso, M., Lestiani, D.D., Lim, J.M., Rahman, S.A., Elias, M.S., Shagjjamba, D., Markwitz, A., Waheed, S., Siddique, N., Pabroa, P.C., Santos, F.L., Seneviratne, M.C.S., Handagiripathira, L., ... Karydas, A. (2016). The APAD and ASFID: Long-term fine and coarse ambient particulate matter and source fingerprint databases for the Asia-Pacific region. Air Quality Clim. Change 50: 41-49.

Badan Pusat Statistik (BPS) (2018). Jumlah Penduduk dan Rasio Jenis Kelamin Menurut Kabupaten/Kota di Provinsi DKI Jakarta, 2015. https://jakarta.bps.go.id/subj ect/12/kependudukan.html\#subjekViewTab3

Bappenas (2006). Strategi dan rencana aksi nasional dan 5 kota besar untuk peningkatan kualitas udara perkotaan. (In Indonesian). https://www.bappenas.go.id/id/berita-dansiaran-pers/berita/strategi-dan-rencana-aksi-nasional-dan5-kota-besar-untuk-peningkatan-kualitas-udara-perkotaan/

Baxter, P.J. and Horwell, C.J. (2015). Chapter 60 - Impacts of Eruptions on Human Health. In The encyclopedia of volcanoes (Second Edition), Sigurdsson, H. (Ed.), Academic Press, Amsterdam, pp. 1035-1047.

Begum, B.A. and Biswas, S.K. (2008). Trends in particulate matter (PM) and lead pollution in ambient air of Dhaka City in Bangladesh. J. Bangladesh Acad. Sci.. 32: 209217. https://doi.org/10.3329/jbas.v32i2.2427

Begum, B.A., Biswas, S.K., Markwitz, A. and Hopke, P.K. (2010). Identification of sources of fine and coarse particulate matter in Dhaka, Bangladesh. Aerosol Air Qual. Res. 10: 345-353. https://doi.org/10.4209/aaqr.200 9.12.0082

Begum, B.A., Biswas, S.K. and Hopke, P.K. (2011). Key issues in controlling air pollutants in Dhaka, Bangladesh. Atmos. Environ. 45: 7705-7713. https://doi.org/10.1016/ j.atmosenv.2010.10.022

Begum, B.A. and Hopke, P.K. (2019). Identification of sources from chemical characterization of fine particulate matter and assessment of ambient air quality in Dhaka, Bangladesh. Aerosol Air Qual. Res. 19: 118-128. https://doi.org/10.4209/aaqr.2017.12.0604

Betha, R., Pradani, M., Lestari, P., Joshi, U.M., Reid, J.S. and Balasubramanian, R. (2013). Chemical speciation of trace metals emitted from Indonesian peat fires for health risk assessment. Atmos. Res. 122: 571-578. https://doi.org/ 10.1016/j.atmosres.2012.05.024

Biswas, S.K., Tarafdar, S.A., Islam, A., Khaliquzzaman, M., Tervahattu, H. and Kupiainen, K. (2003). Impact of unleaded gasoline introduction on the concentration of lead in the air of Dhaka, Bangladesh. J. Air Waste Manage. Assoc. 53: 1355-1362. https://doi.org/10.1080/10473289. 2003.10466299

Brauer, M., Freedman, G., Frostad, J., Van Donkelaar, A.,
Martin, R.V., Dentener, F., van Dingenen, R., Estep, K., Amini, H., Apte, J.S., Balakrishnan, K., Barregard, L., Broday, D., Feigin, V., Ghosh, S., Hopke, P.K., Knibbs, L.D., Kokubo, Y., Liu, Y., ... Cohen, A. (2016). Ambient air pollution exposure estimation for the global burden of disease 2013. Environ. Sci. Technol. 50: 79-88. https://doi.org/10.1021/acs.est.5b03709

Chueinta, W., Hopke, P.K. and Paatero, P. (2000). Investigation of sources of atmospheric aerosol at urban and suburban residential areas in Thailand by positive matrix factorization. Atmos. Environ. 34: 3319-3329. https://doi.org/10.1016/S1352-2310(99)00433-1

Cohen, D.D., Stelcer, E., Atanacio, A. and Crawford, J. (2014). The application of IBA techniques to air pollution source fingerprinting and source apportionment. Nucl. Instrum. Methods Phys. Res., Sect. B 318: 113-118. https://doi.org/10.1016/j.nimb.2013.05.093

Commins, B.T. and Waller, R.E. (1967). Observations from a ten-year-study of pollution at a site in the city of London. Atmos. Environ. 1: 49-68. https://doi.org/10.1016/00046981(67)90108-4

Coulson, J. and Ellison, J.K. (1963). A calibration of the filter-paper method of estimation of smoke. Br. J. Appl. Phys. 14: 899-903. https://doi.org/10.1088/0508-3443/1 4/12/317

Cullis, C.M. and Mulcahy, M.F.R. (1972). The kinetics of combustion of gaseous sulphur compounds. Combust. Flame 18: 225-292. https://doi.org/10.1016/S0010-2180 (72)80139-1

European Commission (2018). Indonesia - Volcanic Eruption \& Tsunami 1 Executive Summary.

Google Maps (2018). Sampling sites. https://www.google. $\mathrm{com} / \mathrm{search}$ q $=$ google+map+indonesia\&client=firefox-bab\&tbm=isch\&tbs=rimg:CRHitirGhvaIIjgYfZSVOb_1j7I6Dp-UFSQTvnM5aabb2cHiyXOwo6ilQDAA49H0v 9JkU1HbqRO56KfIo8Npb70XsSoSCRh9lJU5v_16PEd FDIUsE96RyKhIJsjoOn5QVJBMRxqQlG45gG7sqEgm -czlpptvZwREWih

Haryanto, B. (2018). Climate change and urban air pollution health impacts in Indonesia. In Climate change and air pollution: The impact on human health in developed and developing countries. Akhtar, R. and Palagiano, C. (Eds.), Springer International Publishing, Cham, pp. 215-239. https://doi.org/10.1007/978-3-319-61346-8_14

Hopke, P.K., Xie, Y., Raunemaa, T., Biegalski, S., Landsberger, S., Maenhaut, W., Artaxo, P. and David, C. (1997). Characterization of the Gent stacked filter unit $\mathrm{PM}_{10}$ sampler. Aerosol Sci. Technol. 27: 726-735. https://doi.org/ 10.1080/02786829708965507

Hopke, P.K, Cohen, D.D., Begum, B.A., Biswas, S.K., Ni, B., Pandit, G.G., Santoso, M., Chung, Y.S., Davy, P., Markwitz, A., Waheed, S., Siddique, N., Santos, F.L., Pabroa, P.C.B., Seneviratne, M.C.S., Wimolwattanapun, W., Bunprapob, S., Vuongm, T.B., Duy Hien, P. and Markowicz, A. (2008). Urban air quality in the Asian region. Sci. Total Environ. 404: 103-112. https://doi.org/ 10.1016/j.scitotenv.2008.05.039

Ikegami, M., Okada, K., Zaizen, Y., Makino, Y., Jensen, J.B., Gras, J.L. and Harjanto, H. (2001). Very high weight ratios 
of $\mathrm{S} / \mathrm{K}$ in individual haze particles over Kalimantan during the 1997 Indonesian forest fires. Atmos. Environ. 35: 42374243. https://doi.org/10.1016/S1352-2310(01)00247-3

Karrari, P., Mehrpour, O. and Abdollahi, M. (2012). A systematic review on status of lead pollution and toxicity in Iran; Guidance for preventive measures. DARU J. Pharm. Sci. 20: 2. https://doi.org/10.1186/1560-8115-20-2

Khan, M.F., Latif, M.T., Saw, W.H., Amil, N., Nadzir, M.S.M., Sahani, M., Tahir, N.M. and Chung, J.X. (2016). Fine particulate matter in the tropical environment: monsoonal effects, source apportionment, and health risk assessment. Atmos. Chem. Phys. 16: 597-617. https://doi.org/10.5194/acp-16-597-2016

Kim Oanh, N.T., Upadhyay, N., Zhuang, Y.H., Hao, Z.P., Murthy, D.V.S., Lestri, P., Villarin, J.T., Chengchua, K., Co, H.X., Dung, N.T. and Lindgren, E.S. (2006). Particulate air pollution in six Asian cities: Spatial and temporal distributions, and associated sources. Atmos. Environ. 40: 3367-3380. https://doi.org/10.1016/j.atmosenv.2006.01.050

Kristiansen, N.I., Prata, A.J., Stohl, A. and Carn, S.A. (2015). Stratospheric volcanic ash emissions from the 13 February 2014 Kelut eruption. Geophys. Res. Lett. 42: 588-596. https://doi.org/10.1002/2014GL062307

Kurniawati, S., Santoso, M., Lestiani, D.D., Atmodjo, D.P.D., Sari, D.K. and Kusmartini, I. (2019). Identification of Potential Source Location of Sulfur at Urban Area Bandung using Conditional Probability Function (CPF). IOP Conf. Ser.: Earth Environ. Sci. 303: 012042. https://doi.org/10.1088/1755-1315/303/1/012042

Kusmartini, I., Syahfitri, W.Y.N., Kurniawati, S., Lestiani, D.D. and Santoso, M. (2017). Elemental characterization of Mt. Sinabung volcanic ash, Indonesia by Neutron Activation Analysis. J. Phys. Conf. Ser. 860. https://doi.org/10.1088/1742-6596/860/1/012005

Landsberger, S. (1999). Amsterdam, netherland: Gordon and breach science publisher. In Elemental analysis of airborne particles, Creatchman, M. (Ed.), CRC Press.

Latif, M.T., Othman, M., Idris, N., Juneng, L., Makmom, A., Hamzah, W.P., Khan, M.F., Nik Sulaiman, N.M., Jewaratnam, J., Aghamohammadi, N., Sahani, M., Xiang, C.J., Ahamad, F., Amil, N., Darus, M., Varkkey, H., Tangang, F. and Jaafar, A.B. (2018). Impact of regional haze towards air quality in Malaysia: A review. Atmos. Environ. 177: 28-44. https://doi.org/10.1016/j.atmosenv. 2018.01.002

Lelieveld, J., Klingmüller, K., Pozzer, A., Pöschl, U., Fnais, M., Daiber, A., and Münzel, T. (2019). Cardiovascular disease burden from ambient air pollution in Europe reassessed using novel hazard ratio functions. Eur. Heart J. 40: 1590-1596. https://doi.org/10.1093/eurheartj/ehz135

Lestari, P. and Mauliadi, Y.D. (2009). Source apportionment of particulate matter at urban mixed site in Indonesia using PMF. Atmos. Environ. 43: 1760-1770. https://doi.org/10.1016/j.atmosenv.2008.12.044

Lestiani, D.D., Santoso, M., Trompetter, W.J., Barry, B., Davy, P.K. and Markwitz, A. (2013). Determination of chemical elements in airborne particulate matter collected at Lembang, Indonesia by particle induced X-ray emission. J. Radioanal. Nucl. Chem. 297: 177-182. https://doi.org/10.1007/s10967-012-2348-z

Lestiani, D.D., Apryani, R., Lestari, L., Santoso, M., Hadisantoso, E.P. and Kurniawati, S. (2018). Characteristics of trace elements in volcanic ash of kelud eruption in East Java, Indonesia. Indonesian J. Chem. 18: 457-463. https://doi.org/10.22146/ijc.26876

Lestiani, D.D, Santoso, M., Kurniawati, S., Sari, D.K., Kusmartini, I., Manurung, A. and Riadi, A. (2019). Chemical composition of fine particulate matter from peat forest fires at Palangka Raya and its dispersion using HYSPLIT. IOP Conf. Ser.: Earth Environ. Sci. 303: 012035. https://doi.org/10.1088/1755-1315/303/1/012035

Menlhk (2018). AQMS. http://iku.menlhk.go.id/aqms/pm25

Mutaqin, B.W., Lavigne, F., Hadmoko, D.S. and Ngalawani, M.N. (2019). Volcanic eruption-induced tsunami in Indonesia: A review. IOP Conf. Ser.: Earth Environ. Sci. 256: 012023. https://doi.org/10.1088/1755-1315/256/1/0 12023

P3KLL, K. (2010). AQMS. http://pusarpedal.menlh.go.i $\mathrm{d} / ? \mathrm{p}=300$

Permadi, D.A. and Kim Oanh, N.T. (2013). Assessment of biomass open burning emissions in Indonesia and potential climate forcing impact. Atmos. Environ. 78: 250 258. https://doi.org/10.1016/j.atmosenv.2012.10.016

Rahman, S.A., Hamzah, M.S., Wood, A.K., Elias, M.S., Adullah Salim, N.A. and Sanuri, E. (2011). Sources apportionment of fine and coarse aerosol in Klang Valley, Kuala Lumpur using positive matrix factorization. Atmos. Pollut. Res. 2: 197-206. https://doi.org/10.5094/APR.20 11.025

Salako, G.O., Hopke, P.K., Cohen, D.D., Begum, B.A., Biswas, S.K., Pandit, G.G., Chung, Y.S., Rahman, S.A., Hamzah, M.S., Davy, P., Markwitz, A., Shagjjamba, D., Lodoysamba, S., Wimolwattanapun, W. and Bunprapob, S. (2012). Exploring the variation between EC and BC in a variety of locations exploring the variation between $\mathrm{EC}$ and BC in a variety of locations. Aerosol Air Qual. Res. 12: 1-7. https://doi.org/10.4209/aaqr.2011.09.0150

Santoso, M., Hopke, P.K., Hidayat, A. and Diah Dwiana, L. (2008). Sources identification of the atmospheric aerosol at urban and suburban sites in Indonesia by positive matrix factorization. Sci. Total Environ. 397: 229-237. https://doi.org/10.1016/j.scitotenv.2008.01.057

Santoso, M, Lestiani, D.D., Mukhtar, R., Hamonangan, E., Syafrul, H., Markwitz, A. and Hopke, P.K. (2011). Preliminary study of the sources of ambient air pollution in Serpong, Indonesia. Atmos. Pollut. Res. 2: 190-196. https://doi.org/10.5094/APR.2011.024

Santoso, M., Lestiani, D.D. and Markwitz, A. (2013a). Characterization of airborne particulate matter collected at Jakarta roadside of an arterial road. J. Radioanal. Nucl. Chem. 297: 165-169. https://doi.org/10.1007/s10967012-2350-5

Santoso, M, Lestiani, D.D. and Hopke, P.K. (2013b). Atmospheric black carbon in $\mathrm{PM}_{2.5}$ in Indonesian cities. $J$. Air Waste Manage. Assoc. 63: 1022-1025. https://doi.org/ 10.1080/10962247.2013.804465

Santoso, M. and Lestiani, D.D. (2014). Application of ED $\mathrm{XRF}$ in supporting national program of air quality 
improvement in Indonesia. XRF Newsl. 26: 8-14. https://inis.iaea.org/collection/NCLCollectionStore/_Pub lic/46/058/46058300.pdf?r=1\&r=1

Santoso, M, Lestiani, D.D., Kurniawati, S., Damastuti, E., Kusmartini, I., Prakoso, D., Dimas., Triyambodo. and Rita. (2019). Elemental composition of particulate matter air pollution collected around industrial area in east Java. IOP Conf. Ser.: Earth Environ. Sci. 303: 012036. https://doi.org/10.1088/1755-1315/303/1/012036

Sattar, Y., Rashid, M., Ramli, M. and Sabariah, B. (2014). Black carbon and elemental concentration of ambient particulate matter in Makassar Indonesia. IOP Conf. Ser.: Earth Environ. Sci. 18: 012099 https://doi.org/10.1088/17 55-1315/18/1/012099

Sharma, S., Sharma, V. and Paliwal, R. (2011). Lead toxicity, oxidative damage and health implications. A review. Int. J. Biotechnol. Mol. Biol. Res. 2: 215-221. https://doi.org/ 10.5897/IJBMBRX11.002
Sulong, N.A., Latif, M.T., Khan, M.F., Amil, N., Ashfold, M.J., Wahab, M.I.A., Chan, K.M. and Sahani, M. (2017). Source apportionment and health risk assessment among specific age groups during haze and non-haze episodes in Kuala Lumpur, Malaysia. Sci. Total. Environ. 601-602: 556-570. https://doi.org/10.1016/j.scitotenv.2017.05.153 Yin, P., Brauer, M., Cohen, A., Burnett, R.T., Liu, J., Liu, Y., Liang, R., Wang, W., Qi, J., Wang, L. and Zhou, M. (2017). Long-term fine particulate matter exposure and nonaccidental and cause-specific mortality in a large national cohort of Chinese men. Environ. Health Perspect. 125: 117002. https://doi.org/10.1289/EHP1673

Received for review, November 6, 2019

Revised, June 12, 2020

Accepted, June 14, 2020 